\title{
HOOFDTREKKEN VAN DE ONTWIKKELING VAN SURINAME EN DE NEDERLANDSE ANTILLEN
}

DOOR

\section{A. JONKERS}

\section{Eerste optreden van de West-Indische Compagnie.}

De Spaanse conquistadores trokken de nieuwe landen in de sfeer der internationale politiek van de 16e en 17e eeuw, waardoor de begeerte van anderen werd geprikkeld. De schatkamers die zij voor Spanje openlegden, verschaften dit land de middelen om zijn kostbare oorlogen in Europa te financieren. Het onderscheppen van de aanvoer dezer schatten en het bestrijden van de vijand in de wateren om de nieuwe bezittingen was voor Engeland, Frankrijk en de Verenigde Nederlanden een voor de hand liggende strategie. Want deze landen beschikten over een groot aantal stoutmoedige vissers en kustvaarders, die gaarne bereid waren hun bedrijf voor meer winstgevende en avontuurlijker exploraties op te geven. Velen hunner hadden meerdere reizen vanuit de Iberische havens voor Spaanse en/of Portugese rekening naar de overzijde achter de rug en kenden dus de weg naar de verre overwal. De handwerkslieden en kooplieden wisten de geest van expansie, die de landen aan de Noordzee doorvoer, te kanaliseren en zich te ontwikkelen tot kooplieden van groot formaat, georganiseerd in grote handelscompagnieën. ,It is almost as though unnumbered swarms of unknown little men suddenly thronghed on to a stage from which the great actors had passed" (NEwTON, p. 133).

Zo kwam op 3 Juni 1621 de West-Indische Compagnie tot stand aan wie het uitsluitend recht werd toegekend om te bevaren en handel te drijven op de landen van Afrika, gelegen ten Zuiden van de kreeftskeerkring tot Kaap de Goede Hoop, die van Noorden Zuid-Amerika van de zuidelijke punt van New Foundland af en verder op alle kusten en eilanden gelegen ten westen van de

$$
-113-
$$


meridiaan van Kaap de Goede Hoop tot de meridiaan van Nieuw Guinea. De Compagnie oefende namens de Staten-Generaal souvereiniteitsrechten uit, zij kon bezittingen verwerven en verdragen maken. Ook had zij, hoewel het charter dit niet noemde, de contrôle op de slavenhandel omdat zij de gehele handel regulariseerde. Haar handelsmonopolie was niet absoluut. Met haar toestemming konden particulieren deelnemen aan de handel en de vaart op de landen die onder haar monopolie vielen tegen betaling van recognitie. Hiermede was een verdeling van invloedsferen tussen de eerder opgerichte Oost-Indische Compagnie en de West-Indische Compagnie tot stand gekomen, analoog aan die van Paus Alexander VI in 1493, waarbij de wereld werd verdeeld in een ontdekkings- en exploitatiegebied voor Spanje en een voor Portugal.

Sindsdien hebben de Nederlanden hun aandeel, en een belangrijk aandeel, gehad in de strijd die de opkomende Europese naties in de Amerikaanse wateren tegen het wereldrijk Spanje voerden. Verschillende landen en eilanden werden in bezit genomen en moesten weer worden prijs gegeven. Minder dan Engeland en Frankrijk waren de Nederlanders uit op territoriale winst. Hun kracht lag meer in de sluikhandel op de vijandelijke havens in Amerika en de buitvaart, en later in hun concentratie op één doel, de handel. Met uitzondering van de Guyana's, en aanvankelijk de Bovenwindse Eilanden, legden ze zich nergens in hoofdzaak op de landbouw toe. Inbezitname van land en de vestiging van volksplantingen was in hoofdzaak middel en zelden doel. Onder de Fransen en Engelsen daarentegen waren er velen die een nieuw geregeld bestaan als landbouwkolonist wilden winnen, in een maatschappij vrij van geloofsvervolging en vrij van klasse-vooroordeel. De Spanjaarden weer hadden als eerste doel de exploitatie van minerale rijkdommen.

De Nederlandse Antillen onder de West-Indische Compagnie.

In het kielzog van Christoffel Columbus ontdekte Alonso DE OJEDA het eiland Curaçao. Onder zijn gezellen bevond zich Amerigo Vespuggi, de naamgever van het nieuw ontdekte werelddeel, die in zijn fantasierijk reisverslag gewaagde van een eiland der reuzen, Isla de los Gigantes, daarbij waarschijnlijk doelende op Curaçao. Volgens een brief van hem, zou dit eiland bewoond zijn door inboorlingen van meer dan normale afmetingen. De Spanjaarden koloniseerden Curaçao, Aruba en Bonaire in 1527-'29. Toen zij er geen schatten aantroffen noemden zij deze 
eilanden ,,islas inútiles”. Zij beoefenden er in hoofdzaak de veeteelt.

JOHANNES VAN WALBEECK veroverde in 1634 Curaçao nagenoeg zonder tegenstand op de Spanjaarden. Het initiatief hiertoe ging uit van de Amsterdamse kamer der West-Indische Compagnie, wier bewindhebbers was verteld dat het eiland gemakkelijk was te verdedigen, zodat het een ideale basis zou zijn voor de scheepsmacht der Compagnie. De prachtige haven, die Curaçao als van nature voorbestemd maakt om als stapelplaats en als centrum van handel op de Noordkust van Zuid-Amerika en het Caraïbisch gebied te dienen, werd door vAN WALBEECK vooral gewaardeerd als oorlogshaven.

Op Curaçao en Bonaire vonden de zeevaarders twee belangrijke producten, verfhout en zout.

Zout was in die tijd voor de Hollanders een moeilijk te verkrijgen goed, sinds zij van levering uit de zoutpannen van Portugal door een Spaans verbod van handel met de Nederlanden - verstoken waren. Zout was in grote hoeveelheden nodig voor de conservering van twee van hun belangrijke exportproducten, haring en boter, en was ook in gezoden toestand een exportartikel naar de Baltische landen. In 1599 voeren reeds 40 grote schepen uit naar een pas ontdekt zout-eiland in West-Indië. Van Bonaire werd al vroeg zout gehaald. Reeds in 1623 was het eiland door een Enkhuizer opgenomen. Sint Maarten komt in 1624 voor het eerst voor in de boeken der West-Indische Compagnie. Drie jaar later rapporteert vAN UYTGEEST over de grote zoutpan op dit eiland. In een accoord van 1648 tussen Frankrijk en Nederland wordt gesproken over gezamenlijke zoutoogsten op St. Maarten. Op Curaçao wordt in 1668 met de exploitatie van „,zoutplantages” begonnen. Bonaire leverde in 1623 al verfhout naar Nederland.

Curaçao werd al spoedig een stapelplaats van menselijke koopwaar. Omstreeks 1640 kwamen de kolonisten op de omliggende eilanden tot het inzicht, dat de arbeid in de suikercultuur, die grote winsten beloofde en dientengevolge de aloude tabakscultuur verdrong, voor blanken en Indianen ongeschikt was. Dit leidde tot een grotere vraag naar Afrikaanse slaven, hetgeen de Hollanders in de gelegenheid stelde belangrijke uitbreiding te geven aan de slavenhandel, waarmede zij zich reeds geruime tijd hadden bezig gehouden (omstreeks 1600 verhandelden zij al Afrikanen voor de zoutpannen in Punta Araya, in welk bedrijf zij zich langzamerhand een overwegend belang verwierven). 
De hoofdopzet was vooral Nieuw Nederland via Curaçao van arbeidskrachten te voorzien. Deze opzet werd wel eens verstoord door de voordeliger mogelijkheden die de mensenhandel met de Spanjaarden bood. Curaçao ontwikkelde zich tot belangrijkste slavenmarkt. Zelfs gedurende de z.g. tachtigjarige oorlog met Spanje (die eindigde met de vrede van Munster in 1648), werden slaven voor de omliggende Spaanse koloniën via Curaçao aangevoerd. Zo kochten Spaanse kooplieden op Trinidad in 1605 van de Hollanders een lading slaven (470 stuks), die het volgend jaar door IsaÄc Duchenne werden aangevoerd. Ondanks Engelse concurrentie wist Curaçao zijn positie als eerste slavenmarkt tot het einde der $18 \mathrm{e}$ eeuw te handhaven. Daarnaast werd het eiland een goederen entrepôthaven. Het was economischer om de goederen in grote schepen naar de pakhuizen van Curaçao en St. Eustatius te brengen en ze vandaar uit te distribueren. Bijna alle cacao en tabak van Venezuela werd op deze wijze via Curaçao verscheept, terwijl St. Eustatius een opslaghaven werd voor de indigo en cochenille van Honduras en Campèche.

In de handel en de economische opbouw van de Engelse en Franse eilanden hadden de Nederlandse vrachtvaarders, financiers en handelaren een levendig aandeel. Slaven en goederen werden op crediet geleverd en met producten (retouren) betaald. Het toenmalige Curaçao wordt wel eens het Hongkong van het Caraïbisch gebied genoemd en St. Eustatius het Curaçao van de Bovenwindse Eilanden. De tussenhandel van St. Eustatius kreeg bijzondere betekenis in de Amerikaanse vrijheidsoorlog, toen het Europese goederen doorleverde aan de Noord-Amerikaanse opstandelingen. Ook Curaçao profiteerde - zij het in geringer mate - van de toestand geschapen door de vrijheidsstrijd van de Noord-Amerikanen. Deze lucratieve handel gaf St. Eustatius de naam van ,,de gouden rots". Hier werd voor het eerst een Amerikaanse oorlogsbodem in den vreemde met saluutschoten begroet. In 1781 veroverden de Engelsen het eiland en makten 200 schepen buit. Zij lieten de Nederlandse vlag wapperen, zodat vele niets vermoedende Noord-Amerikaanse schepen, die goederen kwamen halen, in de val liepen. St. Eustatius is deze slag nimmer te boven gekomen.

In de handel hadden Joden een belangrijk aandeel. Evenals in het moederland heerste er in de West-Indische bezittingen, hoewel de Protestantse Kerk staatskerk was, op het gebied van de godsdienst een geest van tolerantie. Spoedig na de Nederlandse inbezitneming immigreerden de eerste Joodse kolonisten. De 
eerste overeenkomst voor de stichting van een Joodse landbouwkolonie werd aangegaan in 1651 met Joño ILHAO. Iets later kwamen de Joodse vluchtelingen uit Brazilië, toen dit land in 1654 van Nederlandse in Portugese handen was overgegaan. Onder hen was een zekere Geosuah DE Mordechay Henriouez, door wiens bemiddeling in 1659 twaalf Joodse families uit Nederland zich hier kwamen vestigen. Hun leider, IsAäc DA CosTA, kreeg een vergunning om een landbouwkolonie te stichten. Vele Joodse immigranten werden handelaars en financiers. Zeer bekende bankiers en handelshuizen dragen nog de naam van HENRIQUEZ of DA COSTA of van de later gekomen MADURo's en CURIËL's.

Het octrooi der eerste West-Indische Compagnie liep af in 1674. In hetzelfde jaar werd een nieuwe Compagnie onder dezelfde naam opgericht, met beperkter octrooi. De Staten-Generaal behield zich nu het recht voor binnen de limites van het Octrooi zelf koloniën te stichten waar de Compagnie geen vestigingen had. Bij elke verlenging werden de rechten der Compagnie beknot. Steeds meer streefde de octrooigever, de Staten-Generaal, naar uitbreiding van de vrijheid van handel.

De gehele Compagniesgeschiedenis door ondervond de handel de weerslag van de herhaalde oorlogen in Europa. Opleving en tegenslag wisselden elkaar af. In 1795 luidde een opstand der slaven een periode van rampspoed in, waarvan de eilanden zich uiterst langzaam herstelden. De Compagnie rekte haar leven tot 1791, toen werd besloten het octrooi niet meer te verlengen aangezien ,,meer en meer duidelijk wordt, dat de Compagnie nutteloos was voor de Staten als voor haar participanten".

Van een eigenlijk gezegd staatsrecht der eilanden was in de Compagniestijd niet veel sprake. De Compagniesvestigingen waren in twee klassen verdeeld. Curaçao, Bonaire en Aruba behoorden tot de eerste klasse en ressorteerden onder de Kamer Amsterdam. St. Eustatius, Saba en St. Maarten waren vestigingen van de tweede klasse. Onder de eerste Compagnie waren deze drie eilandjes patroonschappen, later ressorteerden ze onder de Kamer Zeeland. Aanvankelijk stonden de „lage Regeringen” der eilanden onder een „Hoge Regering” die in Brazilië zetelde. Na het verlies van Brazilië (1654) was er geen duurzaam centraal gezagsmiddelpunt meer in Amerika.•De ordonnantie of het Regeringsreglement van 1629 voor de Amerikaanse gebieden, uitgevaardigd na de inbezitname van Brazilië, bleef nog lang werken, in feite tot de invoering van de Nieuwe Wetgeving voor Suriname en Curaçao in 1869. Alleen voor de eerste klasse vestigingen bestond een 
handelsmonopolie van de Compagnie, in de andere gebieden bestond handelsvrijheid behoudens de betaling van een zeker recht.

De problematiek waarvoor het bestuur zich in de Nederlandse Antillen zag gesteld was heel wat eenvoudiger dan in de omliggende plantage-kolonies der Fransen en Engelsen en in Suriname. Behalve op Aruba was er geen autochthone bevolking. De oorspronkelijke Indiaanse bevolking van Curaçao was (op een twintigtal families na) dadelijk na de verovering met hun Spaanse meesters naar het vasteland overgebracht. De beheersing der slaven was, althans op de Benedenwindse Eilanden, geen dominerend probleem. Hun aantal was geringer en voor het economisch leven waren ze van minder betekenis dan in de landbouwkoloniën. Bovendien konden ze niet zoals in Suriname een toevlucht zoeken in het oerwoud en een bedreiging worden voor hun vroegere meesters.

De vooraanstaande burgers van de eilanden waren te zeer met de handel geoccupeerd om zich erg druk te maken over hun aandeel in het beheer der staatszaken. Dit wil echter geenszins zeggen dat de eigenaars der handelshuizen hun invloed niet wisten te doen gelden als hun belangen op het spel stonden. Integendeel, de patriciërs hadden als het er op aan kwam een belangrijke stem in het kapittel en het kwam wel voor dat de bewindhebbers in Nederland voor gedecideerde opvattingen van de burgerij moesten wijken.

Op Curaçao, onder Amsterdams beheer, berustte het bestuur bij een Gouverneur of directeur en een raad, benoemd door de bewindhebbers. Aanvankelijk werden drie à vier leden benoemd uit burgers en verder maakten de Gouverneur en drie Compagnie's bedienden er deel van uit. Toen langzamerhand meer burgers in de raad zitting hadden gekregen, grepen de Bewindhebbers in, ontsloegen de raad en benoemden een nieuw college, waarin naast de vier Compagnie's bedienden drie burgers werden benoemd, die bovendien uitsluitend voor de behandeling van rechtszaken zitting hadden. Van een door de burgers gekozen vertegenwoordiging was dus geen sprake.

De andere Benedenwindse Eilanden werden bestuurd door een commandeur. Hier had de burgerij in het geheel geen aandeel in het bestuur, hetgeen niet verwonderlijk is, aangezien Aruba tot 1754 voor particulieren was gesloten, terwijl de blanke bevolking van Bonaire in 1714 nog uitsluitend uit dienaren van de Compagnie bestond. 
Tot 1773 ressorteerden de Bovenwindse Eilanden onder de Zeeuwse Kamer der West-Indische Compagnie, daarna nam Amsterdam de administratie over. De vrije burgers op de Bovenwindse Eilanden deden zich gelden als gewapend corps waar tegenover ,het gezag” slechts een zwak garnizoen kon stellen. Ze kozen hun eigen officieren en hun commandant was tevens raadslid. Hierdoor konden ze enige invloed op de bestuurszaken uitoefenen. Soms kwamen ze geducht in het geweer. In 1717 verjaagden de bewoners van St. Maarten een in Nederland benoemde commandeur.

De patroon van St. Eustatius was tevens meester van Saba; later stonden de drie eilanden onder de commandeur van St. Eustatius, er is echter twijfel of de vice-commandeurs wel geheel en al aan de commandeur ondergeschikt waren.

Rechtsbedeling en bestuur waren in één hand. Deze samenvoeging vergrootte de mogelijkheid van bevoordeling van eigen groep door de gezagsdragers, wier keuze niet altijd een gelukkige is geweest.

Van de Staten van de provincie Holland en West-Friesland ging in 1791 het initiatief uit tot het advies om het octrooi van de West-Indische Compagnie niet te verlengen en tot de uitnodiging aan de vergadering van de Heren Bewindhebbers om uit haar midden een commissie te benoemen om met de expresselijk daartoe door de Staten-Generaal te benoemen gecommitteerde ,te treeden in conferentie over de wijze, waarop deeze estimatie en liquidatie casu quo zou dienen te geschieden".

Geconcludeerd werd o.a., dat de Souverein, ,, uit wiens boezem de vorige directie [i.c. van de West-Indische Compagnie] is geproflueert, dezelve nu onmiddellijk op zig neme, en zoodanig gedaante daaraan geeve als meest geschikt en met den welvaart van het algemeen overeenkomstig is".

Voor het bestuur zoude een afzonderlijk college ,, behooren geetablisseert te worden" dat alles zou dienen te verrichten ,wat tot een superieure directie behoort".

Het slot van de deliberatie was, dat op 21 Mei 1791 een resolutie werd aangenomen om tegen 1 Januari 1792 aan het bestaan der West-Indische Compagnie een einde te maken en de ,Bevelhebbers van de Coloniën en Etablissementen" aan te schrijven, teneinde dezelve met den laatsten December van het loopende jaar de Regeering van de Coloniën aanvaarden in naam en wegens Haar Hoog Mogenden".

De maatregel vloeide voort uit de overtuiging, dat van een 
door „mercantiele comptoirgeest" bezield beheersinstituut als de Compagnie, geen afdoende verbetering in de droevige situatie, waarin de koloniën toen verkeerden, kon worden verwacht.

En aldus geschiedde, ondanks bouderen van de Staten van de provincie Zeeland, die zich tegen de overname hadden verzet en de wettigheid der decisie van 21 Mei op goede gronden bestreden. 1 Januari nam een Directie ad interim de teugels in handen totdat in November 1792 de op 1 Juni d.a.v. benoemde Raad van Coloniën in functie kwam. Deze Raad van Coloniën heeft slechts tot 1795 bestaan toen ook Suriname en Berbice, die tot dan een zelfstandige administratie hadden, aan de Republiek werden getrokken.

Alvorens ons verhaal voort te zetten, dienen wij eerst een schets te geven van de lotgevallen van het Nederlandse gewest Suriname aan de noordkust van Zuid-Amerika.

\section{Eerste vestiging in Suriname.}

De scheidingslijn bij welke de Paus de wereld in 1494 in twee invloedsferen verdeelde tussen Spanje en Portugal (Verdrag van Tordesillas) kwam uit in de Guyana's. Vandaar dat dit gebied ten oosten en ten zuiden aan het Portugees sprekende Brazilië en ten westen aan het Spaans sprekende Venezuela grenst. Op deze peripherie vestigden zich Engelse, Franse en Nederlandse kolonisten. Omstreeks 1600 deden de Zeeuwen zich in de omgeving van Guyana gelden. Philips van SPANJE maakte aanspraken op het land. Legio waren echter de klachten der Spaanse autoriteiten over de brutaliteit der geuzen, die 's Konings domein schonden, nederzettingen stichtten en met de inboorlingen pacteerden. Blijkens notariële papieren bestond er in 1613 een Nederlandse vestiging te Paramaribo. Tezelfdertijd was er een Nederlandse vestiging aan de Corantijn. In 1616 vestigde Kapitein Aert Adriaentz Groenewegen met een groep Zeelanders en Engelsen de eerste permanente nederzetting in het huidige Brits Guyana. Het waren de Engelsen die zich het eerste als tabaksplanters aan de Surinamerivier vestigden. Het eerste pogen was niet succesvol maar baande de weg voor de in 1652 door Lord Willoughby, GraAF van Parham gestichte kolonisatie. Hij bracht een aantal Engelse Joden naar een gebied boven Paramaribo, dat nu nog Joden-Savanna wordt genoemd.

Inmiddels hadden de Zeeuwen in Brits Guyana een nieuwe vestiging gesticht, Nova Zeelandia, onder leiding van DAvID 
NASSY, een man die ook bij de eerste penetratie der Nederlanders in de Antillen een rol heeft gespeeld. Hij trof maatregelen voor de vrijwillige immigratie van Joden uit Nederland en onvrijwillige overbrenging van slaven uit Afrika. De eerste suiker uit deze kolonie werd reeds in 1661 te Middelburg ter markt gebracht.

Suriname telde in 1665 ongeveer 40 suikerplantages, genaamd naar de eigenaren of getooid met Bijbelse namen als Gilgall, Bethsheba, Goshen e.d. Zowel de Engelsen als de Nederlanders maakten aanspraak op het gehele gebied tussen de Amazone en de Orinoco. Het kon niet anders of dit moest tot botsingen leiden.

De Europese oorlogen gaven gerede aanleiding tot het uitbreken van vijandigheden. De Nederlandse bezittingen werden in 1661 door major John ScotT op last van Lord WilloughBY overlopen. In antwoord hierop rustten de Staten van Zeeland een vloot uit onder Abraham Crynssen, die in begin 1667 met drie schepen en 600 soldaten Suriname aan de Engelsen ontnam.

Bij de vrede van Breda van 31 Juli van dat jaar werd bepaald, dat iedere partij de vestigingen en landen, die hij op 10 Mei daaraan voorafgaand in zijn bezit had, zou behouden. Intussen was Suriname na 10 Mei door de Engelsen heroverd. De Engelsen weigerden aanvankelijk het land op te geven. Toen hieraan niet meer kon worden ontkomen, besloten zij de kolonisten en alles wat van waarde was zoveel mogelijk mee te nemen, hetgeen de Hollanders trachtten te voorkomen. Het resultaat was een grote verwarring. CRYNSSEN trachtte de situatie te beheersen door een gestreng militair regime, met als gevolg dat het aantal kolonisten, dat wenste te evacueren nog groter werd.

In 1669 had tot rampspoed van de kolonie een uittocht van vele Engelse en een 200 tal Joodse kolonisten plaats, die zich op Jamaica gingen vestigen. Door de bepalingen van de Vrede van Breda hadden de Engelsen in de Guyana's niets meer in handen. De Nederlanders verloren bij die gelegenheid Nieuw Amsterdam, het latere New York.

Inmiddels was er een geschil ontstaan tussen de Staten Generaal der Nederlanden en de Staten der Provincie Zeeland over het eigendomsrecht der kolonie. De Zeeuwen bleken tenslotte in 1683 bereid hun recht van bezit en van bestuur over te dragen aan de West-Indisehe Compagnie voor de som van $f 260.000$.

De Staten-Generaal hadden op 23 September 1682 aan deze Compagnie reeds een octrooi verleend, waarin de verhouding tot het moederland en de bestuursvoering waren geregeld. Dit charter is de grondslag gebleven voor de bewindvoering tot de 
opheffing van de West-Indische Compagnie; het bleef daarna in feite van kracht tot 1816 .

\section{De Geoctroyeerde Societeit van Suriname.}

Het octrooi van 1682 ademde een voor die dagen bijzonder liberale geest en huldigde het principe van deelname der bewoners aan de regeling van hun belangen.

„Dat gelijck het yder een vrij staet met sijn Persoon, Familie, en Goederen” - aldus het charter — ,in de voorszegde Colonie te komen, het oock alsoo sal wesen gepermitteert aan een yegelijck, de welcke alrede sigh daer ter neder gestelt heeft, ofte sal komen te stellen, ten allen tijden van daer te vertrecken met hare Slaven, Beesten, en verdere roerende Goederen".

Ook zal een ieder gronden in bezit mogen nemen en ze te eigen voordele mogen verbouwen naar eigen inzicht, er handel mogen drijven enz.

Alle „Coloniërs en opgezetenen" werd voor tien jaren zonder onderscheid exemptie en immuniteit verleend van alle lasten, met uitzondering van lastgeld van de schepen en weeggeld. $\mathrm{Na}$ ommekomst van die tien jaren zal de Compagnie geen andere heffingen mogen opleggen dan, ,,drie guldens voor yder last dat een schip groot is, voor uytgaen, en gelijcke drie guldens voor inkomen", 50 pond suiker voor iedere opgezetene, źowel blanken als negers, en $2 \frac{1}{2} \%$ van alle goederen die naar het land zullen worden gezonden of aldaar verkocht, ,,ten ware uyt noot ende te gelijckelijck met vrij en liber consent van den Gouverneur ende des Polityequen Raet".

Deze „Polityeque Raet” beoogde te zijn een door ,,alle de Coloniërs" verkozen volksvertegenwoordiging. De leden dienen te worden gekozen ,,uyt de aensienlijckste, verstandighste, en moderaetste onder de Coloniërs". Voor elke plaats werd een dubbeltal bij pluraliteit van stemmen aangewezen, waaruit de Gouverneur dan een keuze deed. „Ende op dat de Coloniërs ende Planters in Suriname, mitsgaders de Ingezetenen met de selve commerciërende, volkomen gerust mogen zijn, dat de voorsz. exemptiën en privilegiën effective sullen werden achtervolght en naergekomen; soo sal de Gouverneur ende den Polityequen Raet, in voege de zelve hier naer sullen werden aengestelt, gehouden zijn op haren Eedt te besorgen, dat daer geen infractiën komen gemaeckt te werden".

En al beantwoordde de practijk niet tenvolle aan de geest van het octrooi, het is toch buiten twijfel, dat de liberaliteit van 
het Nederlands bewind een belangrijke factor was in de ontwikkeling van de landbouw in de Guyana's en van de handel op de gebieden in en om de Caraïbische zee.

Het charter legde op de West-Indische Compagnie zware verplichtingen, waarvan ze het risico blijkbaar niet alleen durfde dragen. Op 21 Mei 1683 deed zij een derde van haar aanspraken over aan de stad Amsterdam en een derde aan de Heer vaN Aerssen, Heer van Sommelsdijck, aan wie krachtens de overeenkomst, met recht van overerving, het ambt van Gouverneur zou toevallen, welk ambt hij zou vervullen ,,uyt liefde, zonder eenige vergeldinghe te ontfangen" ${ }^{1}$ ).

Aldus kwam een merkwaardig condominium tot stand. De nieuwe eigenaars noemden zich de Geoctroyeerde Societeit van Suriname.

In de kolonie heerste toenmaals een toestand van willekeur en anarchie, hetgeen, volgens het getuigenis van van SommeLsDIJCK, voornamelijk te wijten was aan het wanbeheer dat zijn voorgangers - mandatarissen van de Staten van Zeeland - hadden gevoerd.

VAN SommelSDIJCK's komst betekende een begin van geregeld bestuur. Door zijn voorbeeld deed deze ruim denkende, doch ook tyrannieke mens normen van goed en eerlijk beheer ingang vinden. Hem komt de eer toe de bestuurlijke voorwaarden in het leven te hebben geroepen voor de latere bloei van de plantagekolonie.

Voor deze bloei is van grote betekenis geweest, dat VAN SomMELSDIJCK gehuwd was met een adellijke Française. Hij nam een groot aantal Fransen mee, hoofdzakelijk ambachtslieden, die in Paramaribo enige, destijds door Indianen uit Cayenne verdreven landgenoten aantroffen.

De zusters van van Sommelsdijck behoorden tot de volgelingen van de ex-Jezuït JEAN DE LABADIE. Een groep der Labadisten ondernam een kolonisatie-proef op communistische grondslag, die mislukte. De deelnemers bleven in Suriname. De Franse gemeenschap werd na de herroeping van het edict van Nantes nog versterkt door een aantal vooraanstaande Protestantse Franse families. Tot 1783 waren zij in een Waalse gemeente kerkelijk verenigd. ${ }^{*}$ pp het einde der 17 e eeuw waren de Fransen zelfs enige tijd talrijker dan de Nederlanders.

1) De zoon van van Sommelsdijck heeft het ambt op verzoek van zijn moeder geweigerd. Hij sneuvelde bij de afweer van de aanval op de kolonie van Admiraal DE GASSE in 1689. 
De kolonie had trouwens al vroeg een bonte schakering van nationaliteiten binnen haar grenzen. De agrarische politiek die in Suriname werd gevoerd - in tegenstelling tot de mercantiele politiek van de Oost-Indische Compagnie in Indonesië — oefende grote aantrekkingskracht uit op de minder avontuurlijke elementen onder de Europese emigré's. Na de consolidatie van het bestuur hebben zich dan ook weer vele Engelse en Schotse landbouwkolonisten in het gebied gevestigd. Ook Duitsers kwamen naar Suriname. Deze immigranten hadden bij de schrijvers over het oude Suriname geen bijster goede naam. De auteur van de $R e$ marques critiques sur le Tableau Historique zegt: , , Je sais au moins, que les Allemands sont plus cruels que les autres nations, qui habitent cette colonie". De Moravische broeders uit Hernnhut hebben door hun zegenrijk werk in de Surinaamse samenleving de Duitse naam gerehabiliteerd.

Van bijzondere betekenis was ook voor Suriname de Joodse immigratie. Na 1670 groeide het aantal Joden weer snel. Zij vormden, in het bijzonder de Portugese Joden, een aparte groep, die onder het Engelse bestuur in 1665 al bijzondere privilegiën hadden ontvangen. VAN SoMmELSDIJCK roemde hun willigheid, vlijt, genegenheid en eerlijkheid en wenste maar het vierde part te kunnen getuigen van de Christenen.

Hij had het geluk de sympathie en medewerking te hebben van Samuel Cohen Nassy - door Palgrave een moderne Joshua in Israël genoemd - die de vestiging op de Jodensavanna wist te doen herleven.

De aparte positie der Joden gaf in deze kleine maatschappij aanleiding tot wrijvingen, die hun het leven wel eens moeilijk hebben gemaakt. Er zijn zelfs wel eens stemmen opgegaan tot het aanwijzen van een ghetto, maar dergelijke voornemens werden door de directeuren in Holland kordaat van de hand gewezen. De Joden hebben een grote stimulans gegeven aan de plantagecultuur; in het bijzonder de suikercultuur heeft van hun kennis en nijverheid geprofiteerd. In 1730 waren, op een totaal van 400,115 plantages, meest suikerplantages, in handen van Joden.

In de crisis van 1765 , gevolg van windhandel en onoordeelkundige geldleningen, werden de Joden zwaar getroffen. Hun invloed en populariteit taanden; evenals elders werden ze, ook in dit toch overigens zo gastvrije land, bij tijd en wijle voor allerlei tegenslagen verantwoordelijk gesteld. Toch hebben de Joden tot 
op de huidige dag een invloedrijke positie gehandhaafd, hetgeen zij niet alleen te danken hebben aan het feit, dat zij de grootste groep blanke blijvers zijn, maar evenzeer aan hun werklust en bekwaamheid, waardoor zij in de $19 \mathrm{e}$ en $20 \mathrm{e}$ eeuw tot belangrijke posten werden geroepen.

De grootste groep vormden de slaven, die geen zelfstandig burgerlijk bestaan voerden. Velen wisten te ontkomen naar de bossen en sloten zich aan bij de z.g. marroons (van het Spaanse cimarrones). De eerste groepen marroons bestonden uit ontvluchte slaven van de Engelsen en Joden die in de jaren 1667-1669 de kolonie hadden verlaten. De ontsnappingen trachtte men tegen te gaan door een streng regiem, want een plantage zonder slaven was een lichaam zonder ziel. De economische basis was de productie van stapelproducten voor de Europese markt. De economische eenheid de plantage, een bedrijfsvorm als de Romeinse ,villa” gebaseerd op slavenarbeid, welke vorm in de nieuwe tijd alleen in Brazilië, West-Indië en de Zuidelijke staten van de V.S. is herleefd. Aantasting van deze grondslag trof de kolonie in haar hart. De bedreiging der bosnegers was tweeledig le. de aantrekkingskracht die ze uitoefenden op de slaven; $2 \mathrm{e}$. het voortdurende gevaar voor lijf en goed.

Het is dan ook niet te verwonderen, dat het beleid van de bestuurders voor een groot deel werd bepaald door de zorg voor de veiligheid der nederzettingen.

Aldus, in ruwe trekken geschetst, zag de merkwaardige conglomeratie, de Surinaamse samenleving, eruit, waarvan het bestuur, van van SommelsDiJck tot het eind der Napoleontische tijd, werd beheerst door het charter van 1682 .

De eerste Mei 1684 stelde van Aerssen van Sommelsdijck de eerste vertegenwoordigende Raad in, n.l. de Raad van Politie en Criminele Justitie, bestaande uit 8 leden. Het octrooi voorzag in een Raad van Politie van 10 leden en een Raad van Criminele Justitie. VAN Aerssen verdedigde de onvolledige voorziening door te schrijven, dat ,geen persoon tien mijlen in het ront woonende, daer een vierde part van een bode, laet staen een Raetsheer van soude konnen maecken. Dog Horatius maeckten wel van een Cray een Pauwe".

Eerst in 1689 werd een afzonderlijke Raad van Criminele Justitie van 6 leden, in 1744 aangevuld tot 10, ingesteld.

De ,verkiezingen" voor deze vertegenwoordigende organen 
hadden plaats volgens een bijna algemeen stemrecht der blanke kolonisten. Voor de Politie-Raad werden door alle kolonisten dubbeltallen voorgedragen waaruit de Gouverneur een keuze deed. De keuze geschiedde voor het leven. Deze Raad was dus wel heel iets anders dan we nu onder een verkozen volksvertegenwoordiging verstaan.

Door de structuur van het economische leven en de daarop aansluitende indeling van de bevolking in plantage-eigenaars en slaven droeg de kolonie meer het karakter van een exploitatiekolonie dan van een volksplanting. De politieke rechten der blanke meesters zijn evenwel niet altijd onverkort gehandhaafd gebleven. Herhaaldelijk werd inbreuk gemaakt op de constitutie. Hierdoor ontstonden veelvuldige conflicten. Verder schijnt omstreeks het midden der $18 \mathrm{e}$ eeuw een ruim gebruik te zijn gemakt van de in het octrooi opgenomen mogelijkheid voor de raad om zichzelf aan te vullen, indien een verkiezing door de vermeerdering der bevolking ondoenlijk zou zijn, dan wel tot wanorde zou leiden.

De rechtspraak in civiele zaken was opgedragen aan een raad van civiele justitie van 6 leden, gekozen door de Gouverneur, voorzitter van deze raad, uit dubbeltallen opgemaakt door de Raad van Politie uit ,,aansienlijcke en verstandighe inwoners".

In 1753 wendde een aantal van deze ,,aansienlijcke" inwoners zich tot de Staten-Generaal met klachten en grieven tegen de wijze van bestuursvoering. Het ongewilde gevolg was dat de staatkundige rechten der burgers, in plaats van verruimd, in het belang van een daadwerkelijk bestuur werden bekort. En aldus bleef de situatie tot de Societeit - waaraan de familie vaN Aerssen van Sommelsdijck sinds 1770, door verkoop van haar belang aan Amsterdam, geen deel meer had - in 1795 werd ontbonden.

Het geheel van het tijdperk overziende, treft het zovele trekken van het autocratisch regentenbestuur van de Lage Landen in het bestel dezer kolonie weerspiegeld te vinden.

De economische situatie was in de loop der $18 \mathrm{e}$ eeuw verslechterd. Vooral in de eerste helft werden vele plantages geteisterd door aanvallen van weggelopen slaven. Dit gevaar verminderde, nadat een verdrag was gesloten met één der Afrikaanse stammen. Sindsdien kende men ",bevredigde bosnegers" en "marrons”, welke laatsten echter geen acuut gevaar meer vormden.

De 400 à 500 plantages ondervonden grote weerslag van de 
reeds eerdergenoemde economische crisis van 1775. De goede prijzen voor tropische koloniale producten had een ruim aanbod van leningen door Amsterdamse financiers tengevolge, die in vele gevallen niet oordeelkundig werden besteed. Kunstmatige koersdalingen van aandelen, als gevolg van geruchten verspreid door speculanten, ondergroeven het vertrouwen in Surinaamse beleggingen. Een crisis op de Amsterdamse beurs deed het Surinaamse crediet opdrogen, waardoor vele planters genoodzaakt werden hun plantages aan de schuldeisers over te doen. Deze nieuwe ,,afwezige" eigenaars stelden beheerders aan, die geen ander belang hadden dan zo spoedig mogelijk rijk naar het vaderland terug te keren. „Het rijk der Surinaamse planters spoedde ten einde, dat der Administrateurs begon" (WolBers). Dit absenteïsme verzwakte de samenleving moreel en economisch en was oorzaak van vele misstanden, die mede een verklaring vormen voor de deplorabele toestand waarin de Sociëteit van Suriname bij het vervallen van het octrooi verkeerde.

De periode van overgang (I795-I8I5).

De hiervoren genoemde Raed van Coloniën (blz. 120) werd in 1795 vervangen door een ,Committee tot de Zaken van de Coloniën en Bezittingen op de kust van Guinea en in Amerika", van 21 leden, dewelke nog de verovering van Curaçao door de Engelsen beleefde, om op 2 Januari 1801 te worden vervangen door een 5 leden tellende „,Raad voor het Bestuur van de West-Indische Bezittingen en Coloniën in Amerika en op de kust van Guinea". Dit lichaam moest voor elk der koloniën een charter ontwerpen, welke opdracht niet is uitgevoerd. De elkaar snel opvolgende regelingen, die het moederland tot de bevrijding van de Fransen trof, bleven zonder enige uitwerking overzee.

Suriname was in 1799 in handen van de Engelsen gevallen, welke bezetting, behoudens een korte onderbreking tussen 1802 (vrede van Amiëns) en 1804, tot 1815 duurde. Gedurende de eerste periode bleef de Nederlandse Gouverneur in zijn functie gehandhaafd; daarna zijn een aantal Engelse functionarissen opgetreden. De bestuursinrichting bleef echter ongewijzigd.

Curaçao, dat, na een Engelse occupatie van 1800-1803, weer in handen der Nederlanders was gekomen, werd op 1 Januari 1807 wederom door de Engelsen veroverd, hetgeen evenmin ingrijpende hervormingen in het bestuur teweeg bracht. 
De periode van I8I5-I865.

Na het verdrag van 1814 met Engeland bleken de Nederlandse bezittingen in Amerika te zijn teruggebracht tot een deel van Guyana en zes kleine eilanden. Het grootste deel van Guyana, te weten de vestigingen aan de rivieren Berbice, Demarara en de Essequibo werden aan Engeland afgestaan.

Voor het deel der koloniën, dat van Engeland werd terugontvangen werd een nieuw staatsrechtelijk bestel gecreëerd. Voor de West had dit tot gevolg, dat bij Koninklijk Besluit van 14 September 1815 No. 58 drie koloniën werden ingesteld n.l. Suriname (onder een Gouverneur-Generaal), Curaçao en onderhorigheden (tezamen vormende een Gouvernement-Generaal) en de Bovenwindse eilanden St. Maarten, St. Eustatius en Saba (één Gouvernement).

In Suriname was het uitvoerend gezag in handen gelegd van de Gouverneur-Generaal. Een Hof van Politie stond hem terzijde. Dit hof was een bestuurs- en wetgevend college; de wetgeving stond onder supervisie van de Kroon. Het bestond uit 9 leden, te benoemen uit een voordracht van drie op te maken door het Hof, ditmaal uit de ,,aanzienlijksten, kundigsten en gegoedsten”, zijnde eigenaren van plantages en ,,mitsdien bij de welvaart der volksplanting het meest geïnteresseerd". De zittingsduur was negen jaar en de Gouverneur-Generaal bekleedde het voorzitterschap. Van een gekozen vertegenwoordiging was derhalve geen sprake.

Het Hof had alleen een bestuurlijke taak indien de GouverneurGeneraal het in die zaken betrok. Alleen voor keuren, waarin strafbepalingen waren opgenomen of wel waarbij belastingen werden vastgesteld, was raadpleging van het Hof obligatoir. Het Hof oefende de civiele justitie uit; de criminele rechtspraak werd het voorlopig opgedragen in afwachting van de instelling van een Hof van Justitie. Deze verbinding van wetgevende en uitvoerende macht bleef gehandhaafd tot de invoering van het regeringsreglement van 1865 . Bij de samenvoeging der WestIndische koloniën in 1828 - waarover straks meer - kwam een nieuw regeringsreglement voor Suriname tot stand, dat slechts een leven tot 1832 beschoren was, en waarbij de invloed van het Hof van Politie - omgevormd tot „Hooge Raad der West-Indische Bezittingen" - nagenoeg geheel werd uitgeschakeld. (Onder vigeur van dit reglement werd eindelijk het Hof van Civiele en Criminele Justitie ingesteld). 
In $1832 \mathrm{kwam}$ er weer een naamswijziging en werd de ,Koloniale Raad" ingesteld, die bestond uit de Gouverneur-Generaal als voorzitter, de Procureur-Generaal, de Administrateur van Financiën en zes - wederom aanzienlijke - ingezetenen, zijnde gedeeltelijk in de kolonie woonachtige grondeigenaren en gedeeltelijk vertegenwoordigers van absente grondeigenaren. De wetgevende bevoegdheden van de Koloniale Raad waren evenzeer beperkt. Uit de leden werden de z.g. heemraden gekozen, die in de Surinaamse plattelandsdistricten belast werden met een belangrijke uitvoerende taak. In de practijk waren de particuliere leden van de raad uitsluitend betaalde agenten van absente plantage-eigenaars. Hun positie en hun verkiesbaarheid was afhankelijk van de luimen van hun principalen. Deze bestuursregeling is ten rechte een ,betreurenswaardige schepping”, een ,,plantocratie” en een ,,caricatuur van politieke vrijheid" genoemd. Een parlementslid sprak in 1865, de afgelopen vijftien jaar overziende, van ,,een periode van verwaarlozing en dwang, van schreeuwende willekeur, onbillijkheid, ja, gepleegd onrecht".

Het K.B. van 14 September 1815 No. 58 arresteerde eveneens een ,,Reglement op het beleid van de Regering, het Justitie-wezen den Handel en Scheepvaart op Curaçao en onderhoorige Eilanden" en eenzelfde wetsproduct voor de Bovenwindse Eilanden. Het hoogste uitvoerende gezag was in Curaçao aan de GouverneurGeneraal opgedragen, en op de Bovenwindse Eilanden aan de Gouverneur. St. Eustatius en St. Maarten (waaronder Saba) hadden elk een Raad van Politie. De Gouverneur zetelde op St. Eustatius. Het gezag op het Hollandse deel van St. Maarten werd, onder de orders van de Gouverneur, uitgeoefend door een commandeur. Ook Curaçao kende een Raad van Politie, bestaande uit 3 ambtelijke leden, waaronder de Gouverneur-Generaal als voorzitter, en vier der meest gequalificeerde ingezetenen, te benoemen door de Gouverneur-Generaal, uit een voordracht van de raad van drie personen voor elke vacature.

Elk der eilandbesturen behartigde eigen zaken zelfstandig. Op de Bovenwindse Eilanden regelde het gerechtshof zijn uitspraken nog volgens de ,Orde van regering in plaatsen veroverd en te veroveren in de West Indiën van 1629". Het huwelijksrecht werd op deze verre eilanden beheerst door een ordonnantie van de Staten van Holland van 1580. 
In het jaar 1828 zijn de gezamenlijke Nederlandse West-Indische bezittingen verenigd onder één administratieve kop, een Gouvernement-Generaal. De gedachte ging uit van KonING Willem I. In de nieuwe situatie was er aan elke schijn van zelfbestuur een einde gemaakt. Alle macht kwam toe aan de Landvoogd in Paramaribo. Deze samenvoeging heeft tot 1845 geduurd; lang genoeg om aan te tonen, dat van een samenvoeging van Suriname en de Nederlandse Antillen, die in aard en betekenis zo verscheiden zijn, geen heil kan worden verwacht. Het enige voordeel van de ervaring van 1828-1845 is wellicht, dat deze gedachte, toen ze na de tweede wereldoorlog weer eens opdook, geen steun vond.

Het Surinaams Hof van Civiele en Criminele Justitie was in deze periode aangewezen als appèlcollege voor de rechtspraak op de eilanden (tussen 1830 en 1845 heeft geen enkel appèl plaats gevonden). Iedere kolonie kreeg een overigens ondergeschikt gemeentebestuur. Voor de huishoudelijke behoeften werden de gemeenten ,een gepast en toereikend inkomen” verzekerd (de gemeente Suriname, en de gemeenten Curaçao, St. Eustatius en Saba, en later ook St. Maarten). Curaçao kreeg een directeur en St. Eustatius en Saba gezamenlijk een commandeur, terwijl het bestuur van St. Maarten eveneens onder een commandeur stond, allen rechtstreeks ondergeschikt aan de Gouverneur-Generaal te Paramaribo. Curaçao kende naast het gemeentebestuur nog een raad van politie onder voorzitterschap van de directeur, welke meer algemene zaken zoals rechtspleging, defensie e.d. ter verzorging had. Het autoritair karakter van het stelsel wordt hierdoor getypeerd, dat van de Raad van Politie op Curaçao werd gezegd, dat deze slechts is ingesteld om de gezaghebber, indien deze zulks wenst, te adviseren. Van de toch al beperkte bevoegdheden van die raad bleef in de practijk nagenoeg niets over. En op de Bovenwindse eilanden was het, al ontbrak op St. Eustatius en Saba het ambtelijke element in de raad, geen haar beter.

In 1833 verdwijnen de gemeentebesturen op de eilanden en de Raad van Politie op Curaçao en worden niet minder dan drie koloniale raden gevormd, één op Curaçao, één op St. Eustatius en één op St. Maarten, bestaande uit benoemde leden. Het hoofd der eilandbesturen wordt dan gezaghebber genoemd.

In 1845 werd de fout der samenvoeging erkend. Een der overwegingen, n.l. om de tekorten van Curaçao ten laste van Suriname te brengen, was een hersenschim gebleken, aangezien Suriname zelf onderstand was gaan behoeven. In de jaren 1833-1842 
hebben de zes eilandjes het moederland $f 1.827 .000$ gekost. De verwachting was voorts, dat door deze samenvoeging de landbouw van Suriname en de scheepvaart en handel der Antillen aan elkaar dienstbaar zouden kunnen worden gemaakt. Enige meerdere kennis van deze gebieden en het werelddeel waarin zij zijn gesitueerd, had de moederlandse Regering ook voor deze illusie kunnen behoeden.

De Bovenwindse Eilanden werden nu voor het eerst met de Benedenwindse Eilanden samengevoegd en wel tot de kolonie „Curaçao en onderhorigheden". De positie van de Koloniale Raad op Curaçao blijft een adviserende, op de andere eilanden wordt aan de gezaghebber een adviserende commissie van twee leden toegevoegd.

De afscheiding der Nederlandse Antillen van Suriname maakte uiteraard nieuwe constitutionele voorzieningen nodig. Voor Suriname kwamen deze in 1845 tot stand.

Slechts die veranderingen werden in het bestaande regeringsreglement aangebracht, welke door de splitsing noodzakelijk waren. Aan het bestuurssysteem werd niets gewijzigd.

Voor Curaçao kon, in verband met de samenvoeging met de Bovenwindse Eilanden, niet met zulk een eenvoudige herziening worden volstaan. De nieuwe regeling werd in 1848 van kracht. De titel van de Landvoogd werd en bleef sindsdien - evenals voor die van Suriname - Gouverneur. De macht des Landvoogds was ook nu practisch ongebreideld. Wel kreeg hij een adviserende raad (Koloniale Raad) naast zich, van 4 particuliere en drie ambtelijke leden, doch wederom was bepaald, dat alleen aan de Gouverneur de bevoegdheid toekwam zaken ter tafel te brengen. Over algemene verordeningen moest de raad worden gehoord. Nieuw was de bepaling, dat een aangelegenheid ter beslissing aan het Ministerie van Koloniën moest worden voorgelegd, wanneer de Gouverneur de inwilliging weigerde van een verzoek tot behandeling van een of meer der leden. Het toezicht van de Kroon op de wetgeving bleef gehandhaafd. Alleen in dringende gevallen mocht de Landvoogd een wettelijke regeling onder nadere goedkeuring afkondigen. Belastingen behoefden altijd voorafgaande goedkeuting des Konings. Ondergeschikte keuren en bepalingen van politie kon de Landvoogd zonder toezicht vaststellen. Uiteraard moest ook de begroting door de Kroon worden goedgekeurd evenals vervreemding van vaste eigendommen, welke bevoegdheid tevoren zonder hoger toezicht de Landvoogd toekwam. 
De eilanden buiten Curaçao bleven bestuurd door een gezaghebber, bijgestaan door een adviserende commissie te benoemen door de Gouverneur. Zelfs deze benoemingen van uitsluitend plaatselijk belang moesten door de Kroon worden bevestigd. Aldus de belangrijkste voorzieningen, waaruit blijkt, dat de bevolking nog steeds elke reële medezeggenschap in 's lands bestuur werd ontzegd.

\section{De regeringsreglementen van 1865.}

De grote herziening van 1865 bracht hierin voor de WestIndische eilanden, in schrijnende tegenstelling tot Suriname, geen verbetering. Voor Suriname werd op het stuk der volksvertegenwoordiging een voor die tijd grote vrijgevigheid betracht, terwijl voor Curaçao een zeer grote beperking werd in acht genomen. Naar het oordeel van de Regering kon Suriname aanspraak doen gelden op herinvoering van een vertegenwoordigend stelsel. Voor dit rijksdeel betekende dit immers een ,hernieuwing der voorregten bij die fundamentele conditiën (het octrooi 1682) aan de ingezetenen geschonken". Voor de West-Indische eilanden meende men niet verder te moeten gaan dan de instelling van een benoemde raad, die in het openbaar zou meeregeren.

De Minister kon zich hierbij beroepen op een uitspraak van de Koloniale Raad naar welk oordeel ,,van volksgeest, vaderlandsgezindheid, kennis der algemene belangen" bij de bevolking, nu en in een lang verschiet niets te verwachten viel, terwijl ook geen verlangen zou bestaan naar een aandeel in het bestuur, met uitzondering van enkelingen ,,uit de begeerte tot voldoening aan eigen eerzucht". Ook de geografische gescheidenheid werd een bezwaar geacht, ,,de enige band die de eilanden verbindt is hun onderhorigheid aan de Nederlandse Staat".

Een derde bezwaar werd gezien in de beperktheid van het kiezerscorps. Bij een census van $f 20$ zou dit slechts uit 143 personen bestaan. Voor Suriname was naast vier benoemde leden gedacht aan één statenlid op 200 kiezers met een minimum van 9 verkozen leden. Volgens de Gouverneur van Suriname zou het kiezerstal bij een census van $f 20$ nog geen 900 bedragen ${ }^{1}$ ).

Overtuigend is de argumentatie voor de discriminerende houding ten aanzien van Curaçao en Onderhorigheden niet. Suriname was evenals de Antillen schaars bevolkt (52824 zielen

1) In 1919 kwamen 674 personen op de kiezerslijst voor, het stemrecht was toen gebonden aan een inkomen van $f 1400$ 's jaars. 
waarvan 36732 slaven, terwijl de Ned. Antillen 32881 zielen telden, waarvan 10447 slaven). Curaçao werd een vertegenwoordigend stelsel onthouden, om niet, aldus de Minister van Koloniën, , ,de kleederen die de man eerst zouden passen, aan te trekken aan het kind". Kenners van beide koloniën sloegen daarentegen de rijpheid der Antillianen voor een vertegenwoordigend stelsel toen al minstens even hoog aan als die der Surinamers. Niettemin bleef dit verschil tot 1936 gehandhaafd.

De eilanden buiten Curaçao kregen een gemeentelijk stelsel, hetwelk een zekere zelfstandigheid gaf in locale zaken. De gezaghebber (tot 1920 benoemd door de Kroon, later, tot invoering van de eilandenregeling in 1951, door de Gouverneur benoemd) kreeg naast zich twee verkozen landraden. Een splitsing van algemeen en locaal bestuur werd voor het eiland Curaçao zonder gegronde reden geacht. Een scheiding tussen lands- en eilandfinanciën werd niet gemaakt, hetgeen later aanleiding heeft gegeven tot ernstige klachten van Aruba, dat zich benadeeld achtte. Eerst de eilandenregeling van 1951 bracht hierin verandering.

De eilanden konden een begroting bij de Landvoogd voorbrengen, het begrotingsrecht hadden ze niet. Door het ontbreken van het budgetrecht waren aan deze autonomie de tanden ontnomen. Voor het vaststellen van plaatselijke regelingen heeft het instituut nuttig gewerkt.

Beide koloniën werden, aldus de toelichting, privaat- en publiekrechtelijke van de Staat onderscheiden rechtspersonen. Wat voor waarde men aan deze onderscheiding wil toekennen, de rechtspersoonlijkheid der gebieden, die ze ook vroeger hadden, werd door een scheiding der financiën bevestigd. Zo stellig werden deze koloniën als rechtspersonen beschouwd, dat, toen in 1912 de rechtspersoonlijkheid van Nederlands-Indië bij de wet werd vastgelegd, geen behoefte werd gevoeld ook die van Curaçao en Suriname bij de wet te constateren ${ }^{1}$ ).

Het burgerlijk- en strafrecht zouden voor de eerste maal bij Koninklijk besluit worden geregeld en in den vervolge door de organen van het gebiedsdeel, een en ander met inachtneming van het beginsel dat de regeling zoveel mogelijk dient te geschieden overeenkomstig het in Nederland geldende recht.

De gewichtige taak van de vaststelling van de begroting was aan de Koloniale Staten (Suriname) en de Koloniale Raad

1) Bij vonnis van de rechtbank van 's-Gravenhage van 31 Dec. 1929 werd beslist, dat de kolonie Curaçao rechtspersoonlijkheid in de zin van het Burgerlijk Wetboek bezit. 
(Curaçao en Onderhorigheden) overgelaten, met uitzondering van drie gevallen waarin vaststelling bij moederlandse wet was voorgeschreven, en wel: 1e, indien Nederland een tekort op de koloniale begroting moest dekken; $2 \mathrm{e}$, indien de Koning zijn goedkeuring aan de begroting onthoudt; $3 \mathrm{e}$, bij te late vaststelling, nl. na 15 Juli van het jaar, waarin de begroting de Koloniale Staten/ Raad wordt aangeboden.

Hiervan is de eerste uitzondering de belangrijkste. De achteruitgang van de plantage-nijverheid was oorzaak dat - zoals gezegd - ook Suriname armlastig was geworden. Beide koloniën hadden jaar in jaar uit een begrotingstekort, waardoor de hoeksteen der autonomie, het begrotingsrecht, kwam te vervallen.

Dit gaf aanleiding tot tegengestelde reacties. Curaçao was geregeld in verzet tegen het opbrengen van posten op de begroting die beoogden de economische grondslag te versterken. Zo bracht het moederland geregeld uitgaven op voor de bevordering van de landbouw, waarvan de Koloniale Raad voor deze dorre eilanden - terecht - geen heil verwachtte. Gemeend werd, dat deze uitgaven werden opgelegd, om het tekort op de begroting en daarmede de moederlandse inmenging te handhaven. In Suriname daarentegen verweten de Koloniale Staten de moederlandse Regering, dat deze allerlei posten, opgebracht om de welvaart te verhogen, stelselmatig schrapte om het tekort binnen enge perken te houden.

De Koloniale Staten en de Koloniale Raad waren dus voor wat het budgetrecht betreft practisch louter adviserende lichamen, aan wier adviezen de beslissende macht zich bovendien weinig gelegen liet liggen.

In de Regeringsreglementen van 1865 waren een 24 -tal onderwerpen ter speciale regeling aan de kolonie opgedragen, waarbij de gedachte vooropstond, dat het moederland alleen in buitengewone gevallen zou interveniëren. Hieraan werd vrij aardig de hand gehouden tot in 1871 deze practijk werd onderbroken bij de invoering van de drankbelasting. De Staten van Suriname weigerden daartoe een verordening aan te nemen, zolang Nederland niet beter voldeed aan zijn verplichtingen ten aanzien van de immigratie, welke na de afschaffing der slavernij een acute aangelegenheid was geworden. Daarop volgde invoering der belasting bij Nederlandse wet om - zoals de Minister tijdens de parlementaire behandeling opmerkte — , ,aan de Koloniale Staten te doen weten, dat met de stellige bevelen van het Opperbestuur niet de spot mag worden gedreven". 
Daarop volgt opnieuw een periode van zelfbeperking der moederlandse Regering tot 1901 . In dat jaar wordt in de reglementen der beide koloniën een bepaling ingevoerd, krachtens welke elk onderwerp, waarin bij Koloniale verordening is of kan worden voorzien, bij Koninklijk besluit kan worden geregeld. Nadien heeft de moederlandse Regering herhaaldelijk ingegrepen in de autonomie. Haar bemoeienis strekte zich uit tot alle gebieden der landshuishouding. In de practijk vertoonde de positie èn van Curaçao èn van Suriname - ondanks, wat Suriname betreft, de gekozen vertegenwoordiging - een vrij nauwkeurige overeenkomst met die waarin de Engelse kroonkoloniën verkeerden.

Onder deze omstandigheden is de bevoegdheid tot ontbinding van de Staten een overtolligheid en was het recht van initiatief van elke betekenis ontbloot. Van het recht van interpellatie konden beide lichamen - mede dank zij de parlementaire onschendbaarheid der leden — meermalen doeltreffend gebruik maken.

Was het vóór 1840 meestal de Gouverneur die een tegenwicht vormde tegen al te enge behartiging van de eigenbelangen der leden van de vertegenwoordigende lichamen, na 1865 zijn het in Suriname de verkozen vertegenwoordigers der burgerij, die voor het algemeen belang der kolonie op de bres stonden tegenover de financieel te bekrompen politiek van het moederland.

Ook in de samenstelling der vertegenwoordigende lichamen kwam in 1901 wijziging. Krachtens het Surinaamse regeringsreglement van 1865 werden vier van de dertien leden door de Gouverneur benoemd en dus negen verkozen. De Gouverneur was niet langer voorzitter en men meende dat , de denkbeelden en de beschaving van het moederland mede hunne woordvoerders [i.c. de benoemde leden] in dit lichaam behooren te bezitten". In de practijk bleken deze benoemde leden dikwijls de grootste opposanten. In 1901 werd het aantal statenleden op een minimum van 13 en een maximum van 25 gebracht, allen te verkiezen door het kiesgerechtigd deel der bevolking.

In Curaçao had sinds 1865 een deel der Koloniale Raad ambtshalve zitting n.l. de Gouverneur als voorzitter, de procureurgeneraal als vice-voorzitter en de leden van de Raad van Bestuur (waarover hieronder). Hieraan kwam in 1901 een einde; sindsdien werden alle leden door de Koning benoemd. Voor de vervulling van elke opengevallen plaats mocht de Raad een aanbeveling doen van twee personen.

Zowel de Gouverneur van Suriname als die van Curaçao werd 
bijgestaan door een adviserend college, de Raad van Bestuur, bestaande uit 5 leden waarvan hij zelf voorzitter was. Alle leden werden door de Koning benoemd, geschorst en ontslagen. Tot 1901 moest het onder-voorzitterschap worden waargenomen door de procureur-generaal.

De overige wijzigingen in de regeringsreglementen tot 1936 kunnen hier stilzwijgend worden voorbijgegaan.

De staatsregelingen van 1936.

In 1922 komt een grondwetsherziening tot stand waarin een principiële stellingneming met betrekking tot de politiek ten aanzien van de overzeese rijksdelen tot uitdrukking komt. Het woord kolonie verdwijnt dan uit de grondwet. Voor zoveel bij grondwet of wet bepaalde bevoegdheden niet aan de Koning zijn voorbehouden, wordt de uitoefening van het algemeen bestuur opgedragen aan de Gouverneur, op de wijze door de wet te regelen. De Nederlandse wetgever treedt, behalve ter vaststelling der staatsregeling, slechts op indien de behoefte aan regeling bij wet zich voordoet. In principe zal de regeling der inwendige aangelegenheden worden overgelaten aan de Gouverneur in samenwerking met het vertegenwoordigend lichaam. Vernietiging van verordeningen van Suriname en Curaçao zal in den vervolge niet meer bij Koninklijk besluit, maar bij de wet plaats hebben.

Een commissie werd ingesteld teneinde de noodzakelijke herzieningen in de regeringsreglementen voor te bereiden. Uiteindelijk kwam in 1936 voor elk der gebieden een ,wet op de staatsinrichting" tot stand. De voor ons doel voornaamste wijzigingen zijn de volgende:

De verplichting van de Landvoogd tot ,,stipte inachtneming van 's Konings bevelen" werd gewijzigd in ,,opvolging van 's Konings aanwijzingen".

In een besluit van de Gouverneur, de Raad van Bestuur gehoord, kunnen alleen krachtens algemene verordeningen strafbepalingen worden opgenomen. De bepaling dat deze besluiten door de Koning, de Raad van State gehoord, bij met redenen omkleed besluit kunnen worden vernietigd vervangt die volgens welke ,,de Landvoogd tot intrekking of wijziging gehouden was op 's Konings bevel".

Ook Curaçao krijgt een vertegenwoordigend lichaam met de naam van Staten. Het aantal leden voor beide vertegenwoordigingen wordt bepaald op 15, waarvan 5 te benoemen door de 
Gouverneur, en tien te verkiezen. Voor het passief kiesrecht werd een bekwaamheids- en een welvaartsmaatstaf aangelegd.

Nieuw is de regeling van de raadpleging der Staten bij moederlandse wettelijke regelingen, uitsluitend of in belangrijke mate het gebiedsdeel betreffende. Voor zodanig advies kan een termijn worden gesteld. De instelling van autonome rechtsgemeenschappen werd aan de organen van het betrokken gebiedsdeel overgelaten. De eigen-meesterschap had dus in deze regeling een steviger plechtanker gevonden, terwijl de invloed van de bevolking op de gang van zaken was versterkt. Aldus was een ruimer perspectief geopend voor verdere staatkundige ontwikkeling.

Sinds 1929 had het gebiedsdeel Curaçao, dank zij de vestiging van grote olieraffinaderijen op Curaçao en Aruba een sluitende begroting en daarmede zijn financiële autonomie verkregen. Deze situatie trad voor Suriname, dank zij de enorm gestegen revenuen uit de bauxietwinning in met het jaar 1940. Daarna is er van vaststelling der begrotingen door moederlandse organen geen sprake meer geweest. De in de wet vastgelegde principiële gedachte der financiële zelfstandigheid werd daarmee in de practijk uitvoerbaar.

Aldus was de situatie toen de tweede wereldoorlog de verbindingen met het moederland verbrak en ook in de in Amerika gesitueerde Rijksdelen krachten in beweging bracht, die verdergaande hervormingen nastreefden.

\section{Nieuwe oriëntering.}

Op 7 December 1942 hield H.M. Koningin Wilhelmina een rede, waarin $\mathrm{Zij}$ uitdrukking gaf aan de voornemens welke de Nederlandse Regering koesterde met betrekking tot de nieuwe rechtsorde in het Koninkrijk. H.M. zei onder meer:

„Na een historische verbondenheid van eeuwen, waarin het tijdperk van koloniale verhoudingen reeds lang tot het verleden behoorde, stonden wij aan de vooravond van een samengaan op voet van gelijkheid, toen wij plotseling voor de huidige harde beproeving werden geplaatst".

,Ik ben er van overtuigd - en de geschiedenis zowel als de berichten uit de bezette gebieden bevestigen mij daarin - dat het Rijk na de oorlog zal kunnen worden opgebouwd op de hechte grondslag van een volledig deelgenootschap, die de voltooiing zal betekenen van hetgeen in het verleden zich reeds heeft ontwikkeld".

,Ik weet dat geen politieke eenheid en verbondenheid op de duur 
kunnen blijven bestaan, die niet gedragen worden door de vrijwillige aanvaarding en trouw van de overgrote meerderheid der burgerij".

„Ik stel mij voor, zonder vooruit te lopen op de adviezen van de Rijksconferentie, dat zij zich zullen richten op een rijksverband, waarin Nederland, Indonesië, Suriname en Curaçao tezamen deel zullen hebben, terwijl zij ieder op zichzelf de eigen inwendige aangelegenheden in zelfstandigheid en steunend op eigen kracht, doch met de wil om elkander bij te staan, zullen behartigen".

Vrijwillige aanvaarding van een volledig deelgenootschap met eerbiediging van zelfstandigheid in eigen zaken, gedachten, die tot Indonesië, door de Japanse bezetting, niet konden doordringen, doch die in de rijksdelen op het Amerikaanse werelddeel in een vruchtbare bodem vielen.

$\mathrm{Al}$ spoedig na beëindiging van de oorlog werd duidelijk, dat de aangekondigde rijksconferentie, waarvan de voorbereiding reeds in Januari 1942 was begonnen, door de moeilijkheden met Indonesië vooreerst niet zou kunnen worden gehouden.

Wijziging van de staatsregeling in 1948.

Om tegemoet te komen aan de in petities van overzee tot uitdrukking gekomen verlangens, werd in 1947 besloten tot het indienen van wetsontwerpen tot herziening der staatsregeling.

Beoogd werd een overgangsperiode in te luiden, waarin het raam zou kunnen worden opgetrokken voor de verantwoordelijke zelfstandigheid, die het doelwit der hervormingen was.

De mogelijkheid van overdracht van verantwoordelijkheid op eigen organen werd geopend, door de instelling van een College van Algemeen Bestuur voor elk der staatsdelen in Amerika, waarvan de leden na overleg met de Staten en de Raad van Advies (de nieuwe naam voor de vroegere Raad van Bestuur) worden benoemd voor dezelfde periode als de statenleden zitting hebben. Dit college werkt mede met de Gouverneur bij de uitoefening van diens algemeen bestuur, terwijl aan de leden in den regel de uitoefening van de uitvoerende macht wordt opgedragen.

Aldus werd een eigenaardige vorm van semi-parlementaire verantwoordelijkheid gecreëerd. De Gouverneur bleef verantwoordelijk, maar droeg zijn macht in den regel over aan het College van Algemeen Bestuur, dat het vertrouwen van de Staten moest hebben. Bij verschil van mening kon de Gouverneur de overgedragen bevoegdheden weer aan zich trekken. Dergelijke 
conflicten hebben zich in de overgangsperiode niet voorgedaan of zijn althans niet naar buiten getreden.

Een tweede belangrijke hervorming was de invoering van het algemeen mannen- en vrouwenkiesrecht; het kiesreglement diende bij verordening van het rijksdeel te worden vastgesteld ${ }^{1}$ ). Het kiesstelsel moest voldoen aan de beginselen van het algemeen kiesrecht. Benoeming van statenleden was voortaan uitgesloten. Voorts werd de regeling der inwendige aangelegenheden nu tenvolle een autonome bevoegdheid door ze aan de aanwijzingen des Konings te onttrekken. De beperkingen van het budgetrecht werden opgeheven, terwijl de regeling van verplichte krijgsdienst aan de organen van het land werd overgelaten.

Nieuw was het instituut van de vertegenwoordigers der rijksdelen in Nederland, te benoemen door de Gouverneur uit een voordracht van de Staten; de benoeming behoefde de goedkeuring des Konings.

De herzieningswetten kregen 21 Mei 1948 kracht van wet.

Aldus was een belangrijke stap gedaan in de richting van het uiteindelijk doel. Verder gaan stuitte vooralsnog op constitutionele bezwaren. De structuurhervorming waarop de Koninklijke rede duidde kon immers niet in het kader van de vigerende grondwet worden verwezenlijkt.

De grondwetsherziening van 1948.

Daarom werd bij de grondwetsherziening van 1948 een nieuw hoofdstuk aan de grondwet toegevoegd, waarin onder meer werd vastgelegd, dat slechts datgene, wat in gemeen overleg is overeengekomen, de grondslag zal kunnen vormen voor de nieuwe rechtsorde. Met erkenning van de autonome bevoegdheden der rijksdelen om eigen belangen zelfstandig te regelen, wordt de gebondenheid tot de verzorging van de gemeenschappelijke belangen en tot wederkerige bijstand op de voet van gelijkwaardigheid vastgesteld; dit alles onder waarborgen voor de rechtszekerheid, de fundamentele menselijke rechten en vrijheden en deugdelijk bestuur. Overeenstemming bij het te plegen overleg was voor de totstandkoming der definitieve rechtsorde dus een

1) In de ontwerpwetten was in overleg met de overzeese rijksdelen bepaald, dat het verlenen van kiesrecht aan vrouwen aan het betrokken rijksdeel zou worden overgelaten. De Tweede Kamer veranderde het ontwerp in dier voege, dat vrouwenkiesrecht imperatief werd, tot ontstemming vooral van Suriname, dat met de invoering van vrouwenkiesrecht nog had willen wachten. 
conditio sine qua non, terwijl verder is bepaald, dat zij langs democratische weg in elk der grondgebieden moet tot stand komen. De vaststelling van wat onder de gemeenschappelijke belangen moet worden begrepen behoort tot de taak van dit overleg. De naam voor het gebiedsdeel, „Curaçao en Onderhorigheden”, werd, in overeenstemming met een reeds in 1938 in dit rijksdeel tot uiting gebracht verlangen, veranderd in ,Nederlandse Antillen".

\section{De interimregelingen.}

In de veronderstelling, dat de in de Koninklijke rede van 7 December 1942 aangekondigde rijksconferentie met Indonesië en de Amerikaanse rijksdelen nog wel eens zou worden gehouden, werd in 1948 een voorconferentie met Suriname en de Nederlandse Antillen belegd. Beschikt werd over waardevolle rapporten van enige commissies, die zich beijverd hadden de opvattingen te onderzoeken die in Nederland en overzee bestonden omtrent de plaats van de overzeese gebieden in het Koninkrijk. Voorts was inmiddels met Indonesië de overeenkomst van Linggadjati aangegaan, waarin de Nederlands-Indonesische Unie-gedachte was vastgelegd, waarop een aparte structuur Nederland-Suriname-Nederlandse Antillen diende aan te sluiten.

De conferentie kwam tot een aantal resoluties, welke door een redactic-commissio wordon uitgowerlst tot een ontwerp-rijksgrondwet. De Nederlandse Regering echter achtte de regeling te zwaar en de voorstellen daarom geen goede basis voor verdere besprekingen. Intussen werd de definitieve oplossing nog steeds opgehouden door de moeilijkheden met Indonesië. De Nederlandse regering nam toen het initiatief tot het voorbereiden van een verdergaande herziening dan de wijziging der staatsregelingen van 1948, waartoe de grondwet door de invoeging van het nieuwe hoofdstuk XIV nu de mogelijkheid bood. De bedoeling hierbij was het door de Conferentie tot uitdrukking gebrachte verlangen naar volledige eigen-meesterschap in eigen zaken aanstonds te bevredigen en voorts om in afwachting van de definitieve rechtsorde reeds nu meer invloed toe te kennen bij de behartiging der niet interne zaken.

Aldus kwamen de interimregelingen tot stand.

Wat de inhoud van de Interimregelingen betreft moet worden volstaan met de aanduiding van enige hoofdzaken. Met die regelingen werd een volwaardig parlementair systeem ingevoerd in de beide rijksdelen voor de behartiging der inwendige aangelegen- 
heden. De daaraan onttrokken zaken zijn limitatief aangegeven. Zij betreffen de defensie; buitenlandse betrekkingen; regeling van auteursrecht; industriële eigendom; maten en gewichten; de algemene voorwaarden voor uitgifte van zeebrieven; de luchtvaart (uitgezonderd het verlenen van vergunningen voor binnenlandse luchtlijnen); de bevordering der culturele en sociale betrekkingen tussen de rijksdelen en van de financiële en economische betrekkingen tussen Nederland en het betrokken rijksdeel; het toezicht op de algemene voorwaarden, betreffende de toelating, vestiging en uitzetting van Nederlandse onderdanen ${ }^{1}$ ); het overleg omtrent vraagstukken van internationaal karakter inzake munt- en geldwezen, bank en deviezenpolitiek; het toezicht op het internationaal en interregionaal verkeer; de bevordering van de economische weerbaarheid door onderlinge hulp en bijstand, onder waarborg, dat wettelijke regelingen voor beroeps- en bedrijfsuitoefening voor Nederlandse onderdanen gelijkelijk gelden ${ }^{2}$ ).

Voor iedere voor Suriname of de Nederlandse Antillen verbindende wet, moet het betrokken rijksdeel worden geraadpleegd voordat het ontwerp in behandeling komt bij het Nederlandse parlement, aan hetwelk deze adviezen worden voorgelegd. Ook over verdragen met vreemde mogendheden en algemene maatregelen van bestuur een rijksdeel verbindende, is overleg voorgeschreven. De Koning 'mag Suriname of de Nederlandse Antillen niet aan financiële en economische verdragen binden, indien de betrokken regering heeft verklaard van die binding benadeling van de belangen van haar land te duchten. Hetzelfde geldt mutatis mutandis voor toetreding tot en opzegging van dergelijke overeenkomsten.

De Algemene Vertegenwoordiger van het Staatsdeel in Nederland neemt met adviserende stem deel aan het ministerieel overleg over zaken waarbij zijn land betrokken is. Verder is voorgeschreven dat overleg wordt gepleegd over alle aangelegenheden die het rijksdeel raken.

De Koning benoemt na overleg met de Landsregering een

1) In de Interimregeling voor de Ned. Antillen is bepaald, dat dit toezicht wordt uitgêoefend met inachtneming van de bevoegdheid van dit rijksdeel om regelingen te treffen, nodig voor de bescherming van het belang van dat land.

${ }^{2}$ ) In de Interimregeling van de Nederlandse Antillen is dit concordantievoorschrift aan dezelfde beperking onderworpen als bedoeld in de vorige voetnoot. 
staatsraad in buitengewone dienst voor de behartiging van de belangen van het betrokken rijksdeel. Tot nog toe heeft zodanige benoeming nog niet plaats gehad, omdat de rijksdelen daaraan geen behoefte voelden.

Voor de Nederlandse Antillen, wier interimregeling later kracht van wet kreeg, is bepaald, dat ten hoogste drie gedelegeerden de openbare beraadslaging der Staten Generaal kunnen bijwonen en bevoegd zijn mondelinge voorlichting geven in zaken waarbij de Nederlandse Antillen betrokken zijn. Aanvulling van de voor Suriname geldende regeling in gelijke zin bleef achterwege aangezien dit rijksdeel daarop, in afwachting van de definitieve regeling, weinig prijs bleek te stellen.

De Regeringsraad bestaat uit ten hoogste negen Landsministers, de Raad van Advies uit ten minste vijf leden. Het vertegenwoordigend lichaam van Suriname bestaat uit 21 leden, dat van de Nederlandse Antillen uit 22 leden.

Het in de betreffende landsverordeningen neergelegde kiesstelsel is een districtenstelsel. In Suriname verkiest de hoofdstad Paramaribo 10 leden, de overige kieskringen tezamen 11 leden. In het kiesreglement is bepaald, dat de aanwijzing geschiedt volgens het meerderheidsstelsel. Op de Nederlandse Antillen verkiest Curaçao 12 leden, Aruba 8 leden, Bonaire één lid en de Bovenwindse Eilanden één lid. Het kiesreglement regelt hier de aanwijzing der verkozenen per eiland volgens het evenredigheidsbeginsel.

Beide interimregelingen in de redactie zoals ze kracht van wet verkregen, hadden de volledige instemming van de Landsregeringen en volksvertegenwoordigingen in de transatlantische rijksdelen.

De territoriale rechtsgemeenschappen binnen de rijksdelen.

De regeling voor de Nederlandse Antillen bevat voorts enige bepalingen betreffende de zelfstandigheid der eilandgebieden.

Tengevolge van interne moeilijkheden (antagonisme tussen de eilanden Curaçao en Aruba) werd met instemming van het rijksdeel vastgelegd, dat de verdere regeling dezer materie, die overigens een typisch interne zaak der Nederlandse Antillen is, bij algemene maatregel van bestuur (een koninkrijksmaatregel dus) zou geschieden. Aldus kwam de z.g. eilandenregeling tot stand en werd de autonomie der eilandgebieden op Koninkrijksniveau gewaarborgd.

Het bestuur over de eilandgebieden Curaçao en Aruba is in 
handen van een bestuurscollege, bestaande uit de gezaghebber als lid tevens voorzitter, benoemd door de Kroon, en tenminste twee en ten hoogste vier gedeputeerden, te verkiezen door de eilandsraad.

De eilandsraden dezer twee eilanden bestaan uit 21 leden, rechtstreeks gekozen op de voet van algemeen kiesrecht.

De raad voor Bonaire bestaat uit 9 leden, het bestuurscollege uit de gezaghebber en twee gedeputeerden. De Bovenwindse Eilanden hebben een raad van 15 leden, waarvan elk eiland 5 leden kiest. Het bestuurscollege bestaat uit de gezaghebber en zes gedeputeerden, voor elk eiland twee.

De bevoegdheidssfeer is ook hier afgepaald door de opsomming van aangelegenheden die hiertoe niet behoren. De begrenzing der belastinggebieden tussen het Land en de plaatselijke gemeenschappen is zo gekozen, dat de opbrengsten der directe belastingen over het algemeen het betrokken eiland toevloeien (hoewel de wetgeving en de oplegging der aanslagen centraal geschieden), terwijl de in- en uitvoerrechten, accijnzen, zegel- en registratierechten, retributies voor diensten door de Nederlandse Antillen bewezen, de inkomsten van het land vormen.

Het streven is er op gericht geweest de autonomie dezer plaatselijke gemeenschappen alleen te beperken, indien zulks uit hoofde van efficiëncy dan wel op personele, economische of culturele overwegingen bepaald geboden voorkwam.

Behoudens enkele waterschappen en dorpsgemeenschappen kent Suriname tot dusverre geen lagere territoriale rechtsgemeenschappen.

\section{De huidige economische situatie.}

Zoals reeds werd opgemerkt is in de economische positie der beide rijksdelen in de laatste decennia een verandering ten goede gekomen. Op de Nederlandse Antillen is deze teweeggebracht door de in bedrijf stelling van een raffinaderij van de N.V. Curaçaose Petroleum Industrie Mij., een dochteronderneming van de Bataafse Petroleum Mij., op Curaçao (1916) en van een raffinaderij van de Lago Oil en Transport Company op Aruba (1929). Dit betekende een economische omwenteling van de eerste orde. Niet*alleen werden de Nederlandse Antillen economisch zelfstandig, doch zij waren tevens in staat het overheidsapparaat uit te bouwen en de overheidszorg te perfectionneren. De olie-eilanden werden trekpleisters voor de bevolking van in minder gunstige omstandigheden verkerende nabuureilanden, 
ook voor Surinamers. Een indruk van de betekenis der oliebedrijven geven de volgende cijfers. Het in 1951 alleen door de C.P.I.M. aan salarissen uitbetaald bedrag wordt geschat op ongeveer Nf. 107 millioen. Inclusief contractwerken, locale aankopen en andere verplichtingen beliepen de bestedingen omstreeks Nf. 148 millioen, dat is gelijk aan tweemaal de geldcirculatie in de Nederlandse Antillen. Voor de Lago zal deze besomming ongeveer 25 millioen dollar bedragen. De directe en indirecte betekenis van deze inkomsten voor de koopkracht van twee eilanden met tezamen 160.000 zielen is enorm. De dagelijkse aanvoer van ruwe olie op Curaçao was meer dan 430.000 vaten, op Aruba omstreeks 450.000 vaten.

Daarnevens bestaat op Curaçao en Aruba een levendig handelsen toeristenverkeer, terwijl een phosphaatonderneming op Curaçao een 90.000 ton per jaar exporteert.

De eilanden kennen dus een grote voorspoed, welke echter steunt op een zeer smalle economische grondslag. Helaas biedt de natuurlijke gesteldheid weinig vooruitzicht, dat deze basis in de toekomst aanmerkelijk kan worden verbreed.

De situatie van Suriname is een andere. Zeker, ook dit rijksdeel is voor zijn financiële positie grotendeels aangewezen op de inkomsten van één product, de bauxiet. De productie daarvan bedroeg in 1930 ongeveer honderdduizend ton en overschreed in 1952 de 3 millioen ton. Suriname is echter nog steeds een landbouwland, hoewel slechts een klein deel van het vroeger opengelegd gebied nog in exploitatie is. Het uitstel van de afschaffing van de slavernij tot 1863 heeft de ondergang van het plantagesysteem niet kunnen verhoeden. Integendeel er is meer grond voor de stelling, dat dit uitstel Suriname duur te staan is gekomen. Het aangrenzende Brits-Guyana, dat de emancipatie reeds in 1833 doorvoerde, is er steeds veel beter aan toe gebleven, dank zij de immigratie-politiek die de Engelsen aanstonds hebben ingezet en de aanzienlijke investeringen die daarna in die kolonie hebben plaats gevonden.

De onzekerheid omtrent de invloed van de zeker komende emancipatie op de rentabiliteit van het landbouwbedrijf, maakte investeringen in Suriname in de decennia voorafgaande aan de emancipatie te riskant en toen het in 1863 zover was, werd die onzekerheid nog met 10 jaar bestendigd door de instelling van een arbeidsplicht voor de vrijgemaakten. Na deze periode verlieten de meeste arbeidskrachten de plantages om zich op de 
kleinlandbouw toe te leggen of ze vonden in de stad, in de bosbedrijven, bij de balata- of goudwinning en later in de bauxietbedrijven een bestaan.

Remplacering der verloren arbeidskrachten door immigratie van Hindoes en Javanen was niet voldoende om de bedrijven in staat te stellen de mededinging met andere gebieden vol te houden. Hiervoor waren belangrijke investaties nodig en daarvoor was het getij verlopen. De opening van het Suezkanaal had het verre oosten dichter bij de westerse markten gebracht, waardoor Indonesië, dat geen arbeidsvraagstuk kende, een veel aantrekkelijker beleggingsobject werd. De geografische situatie van Suriname ten opzichte van de afzetgebieden was relatief ongunstiger geworden. De zo noodzakelijke vernieuwing der bedrijven bleef achterwege. Kapitaal en intellect vloeiden Indonesië toe.

$\mathrm{Er}$ is wel een en ander gedaan, zowel van overheidswege als door particulieren, om Suriname uit het slop te halen. Tot systematisch onderzoek naar de mogelijkheden van het slechts voor een klein deel geëxploreerde land is het nooit gekomen; ook was de techniek nog niet zo ver gevorderd, dat een onderzoek naar arbeidsbesparende landbouw-productie-methoden, waaraan een land met een arbeidstekort uiteraard behoefte heeft, veel kans op succes zou hebben gehad.

$\mathrm{Na}$ de tweede wereldoorlog ging Nederland over tot de instelling van een ,Welvaartsfonds Suriname”, groot $f 40$ millioen, omdat het begreep dat het verlenen van staatkundige autonomie slechts half werk zou zijn, indien niet tevens de middelen werden verschaft, om de financiële positie van het land minder kwetsbaars te maken en de welvaart een beter fundament te geven.

Het fonds heeft allerlei goede projecten geëntameerd en de grondslag gelegd voor andere. Het was uiteraard verre ontoereikend om alle mogelijkheden van Suriname te onderzoeken en te benutten. Het heeft echter ook de middelen verschaft voor het doen opstellen van een tienjarenplan. De ,Stichting Planbureau Suriname" is medio 1952 met deze taak gereed gekomen. Het ontwerp 10 jarenplan is Augustus van dat jaar ingediend bij de Staten van Suriname. De kosten van het ontwikkelingsplan zijn geraamd op $f 200$ millioen. Daarnevens is nog een project in studie voor de opwekking van energie middels waterkracht, hetgeen mogelijkheden biedt voor de verwerking van bauxiet tot aluminium. Dit is een z.g. „,multipurpose-project”, aangezien het ook dienstbaar kan worden gemaakt aan verdere industrialisatie, de landbouw (irrigatie) en de visserij (in het te vormen stuwmeer). 
Suriname mist de deskundigen, de middelen en ook het crediet om zonder steun van buiten deze ambitieuze plannen ten uitvoer te brengen. De gedachte van de onderlinge bijstand neergelegd in de interimregelingen kan hier zinvolle betekenis krijgen.

De laatste loodjes.

De weg van exploitatiekolonie tot zelfstandig rijksdeel is haast afgelegd. Het sluitstuk, de regeling van de deelname in de gemeenschappelijke belangen, ,,de aangelegenheden van het Koninkrijk", moet nog worden aangebracht. Hierbij zal uiteraard weer in discussie komen wat onder die aangelegenheden moet worden volstaan. De uitkomst van dit beraad kan dus tot gevolg hebben, dat de autonomie uitbreiding of beperking ondergaat. Een regeling waarbij het terrein dier aangelegenheden zoveel mogelijk wordt beperkt, zal aan de overzeese rijksdelen de meeste bevrediging schenken. De besprekingen over het uiteindelijke statuut zijn in April 1952 aangevangen, doch werden onderbroken, toen in Mei tussen de drie partijen nog niet op alle punten overeenstemming was bereikt en nader intern beraad gewenst voorkwam. Het statuut immers moet volgens het grondwettelijk voorschrift zowel door Nederland als door Suriname en de Nederlandse Antillen langs democratische weg (dus door de volksvertegenwoordigingen) vrijwillig worden aanvaard.

De grondslag voor het overleg vormde een werkstuk, bestaande uit 48 punten, dat was opgemaakt door een commissie, bestaande uit Z.E. Mr J. R. H. vaN Schaik, Prof. Mr W. C. L. VAN DER Grinten en Mr W. H. van Helsdingen voor Nederland; $\mathrm{Mr}$ Dr J. A. E. Buiskool en Dr R. H. Pos voor Suriname en Dr M. F. da Costa Gomez, Mr N. Debrot en Dr W. Ch. de la Try Ellis voor de Nederlandse Antillen.

De staatkundige verhouding tot de overzeese rijksdelen raakt vele takken van overheidsbeleid. Zo komt de regeling der defensie op het terrein van de Ministeries van Oorlog en Marine, de verzorging der buitenlandse betrekkingen op dat van het Ministerie van Buitenlandse Zaken en ook op dat van de Departementen van Economische Zaken, Landbouw, Visserij en Voedselvoorziening en Financiën, voor zover het economische en financiële betrekkingen tot het buitenland betreft, en voorts het Departement van Verkeer en Waterstaat, indien het gaat om internationale luchtvaart- of scheepvaart overeenkomsten. De aanpassing van de grondwet aan de nieuwe rechtsorde is een zaak die de Ministeries van Binnenlandse Zaken en Justitie regardeert, ter- 
wijl regeling der financiële verhouding uiteraard de belangstelling heeft van het Ministerie van Financiën.

De Nederlandse delegatie werd dan ook versterkt door een aantal deskundigen. Deze experts hebben het werkstuk bestudeerd met als resultaat een voorstel tot een aantal wijzigingen, die de Nederlandse delegatie grotendeels, soms gewijzigd, heeft overgenomen en nog aangevuld met amendementen harerzijds. De overzeese delegaties hadden het werkstuk niet op dezelfde wijze bekeken en werden dus, hoewel de wijzigingen grotendeels een technisch karakter droegen, geconfronteerd met een werkstuk, dat op vele punten afweek van dat, waarmede ze zich min of meer vertrouwd hadden gemaakt.

$\mathrm{Na}$ langdurig en diepgaand overleg werd in de centrale commissie der conferentie een grote mate van overeenstemming bereikt, zodanig zelfs, dat op een gegeven moment werd verwacht dat nog één vergadering nodig zou zijn om volledig resultaat te bereiken ${ }^{1}$ ).

Echter bleek na behandeling van het ontwerp-statuut van 13 Mei in de drie delegaties, dat bij de Surinaamse delegatie tegen enkele punten van het ontwerp zodanige bezwaren bestonden, dat op dat ogenblik geen bevredigende oplossing te verwachten viel. De meest principiële hiervan waren wel de mogelijkheid van „overruling" in koninkrijksaangelegenheden en het verschil van inzicht over de opname van het zelfbeschikkingsrecht in de preambule van het statuut.

Volgens artikel 7 van het ontwerp-statuut van 13 Mei 1952 zou de Raad van ministers van het Koninkrijk bestaan uit de Nederlandse ministerraad, versterkt met de door de Regering van Suriname onderscheidenlijk van de Nederlandse Antillen benoemde gevolmachtigde minister. Bij de behandeling op regeringsniveau van gemeenschappelijke zaken nemen de vertegenwoordigers der rijksdelen dus aan elk stadium der behandeling deel. Volgens artikel 12 van het ontwerp-statuut kan, indien de gevolmachtigde minister van één der rijksdelen ernstige benadeling verwacht voor zijn land van binding aan een voorgenomen voorziening, de voorziening voor dat land niet worden vastgesteld, tenzij de ministerraad oordeelt, dat de verbondenheid van

1) Het ontwerp-statuut van 13 Mei 1952, waaromtrent een zo grote mate van overeenstemming werd bereikt, is met het werkstuk en andere conferentiestukken opgenomen in de bijlagen van de Handelingen der Tweede Kamer Zitting 1951/1952 No. 2454. 
het land in het Koninkrijk dit eist. Daarmede behoeft de kous niet af te zijn, want de gevolmachtigde minister kan nog voortgezet overleg vragen, dat zal geschieden tussen de MinisterPresident, twee ministers, de gevolmachtigde minister en een door de betrokken regering aan te wijzen gemachtigde. Wensen de gevolmachtigde ministers van beide rijksdelen hieraan deel te nemen, dan bestaat het ,,college voor intern appèl" uit de Minister President, twee ministers en de beide gevolmachtigde ministers. De Raad van ministers moet dan overeenkomstig de uitkomst van het voortgezet overleg beslissen.

Voor koninkrijkszaken die bij rijkswet moeten worden geregeld geldt nog het volgende: Komt zodanige aangelegenheid in de Staten-Generaal in behandeling, dan kan de vertegenwoordiger van het betrokken rijksdeel, die de mondelinge behandeling kan bijwonen en het standpunt van zijn Regering kenbaar maken, zich vóór de eindstemming alsnog tegen het ontwerp verklaren. Indien de Kamer alsdan het voorstel aanneemt met een geringere meerderheid dan drie vijfde van het aantal uitgebrachte stemmen, zou de behandeling worden geschorst en nader overleg plaats vinden in de Raad van ministers (art. 18).

De Surinaamse delegatie meende de regeling voor het intern appèl, welke na veel vijven en zessen was tot stand gekomen, niet te kunnen aanvaarden, omdat de beslissing in feite zou zijn overgelaten aan de Minister-President van het Koninkrijk, die verantwoordelijk blijft aan het Nederlandse parlement. $Z_{\text {ij }}$ zou de regeling alleen acceptabel kunnen achten, wanneer de leiding van dit orgaan een persoon zou zijn, die onafhankelijk staat tegenover de parlementen der landen. Dit voorstel laat zich uiteraard niet rijmen met de parlementaire verantwoordelijkheid en komt dus in conflict met de grondslag van ons staatsbestel.

De weerstand aan Nederlandse zijde tegen het gebruik van het begrip ,,zelfbeschikkingsrecht” is op zichzelf wel begrijpelijk.

Tot nog toe is niemand er in geslaagd voor dit begrip een algemeen aanvaarde definitie te geven. De tekstboeken van het internationale recht erkennen geen wettig recht van zelfbeschikking. Integendeel bedrijft een staat, die een deel van de bevolking van een andere staat bijstaat om zich uit die staat los te maken, volgens het internationale recht een onwettige daad. Secessie en revolutie worden in het volkenrecht niet als wettig erkend.

Toen President WILSON het recht van zelfbeschikking als het ware opnieuw proclameerde dacht hij aan de Europese minderheden en niet aan de koloniale volkeren. De implicaties van dit begrip stonden hem 
zeker niet duidelijk voor de geest. Zijn Minister van Buitenlandse Zaken, ROBERT LANSING, voelde de verwikkelingen al spoedig aankomen. „The phrase is simply loaded with dynamite. What a calamity that the phrase was ever uttered. What misery it will cause." schreef hij in zijn dagboek.

Wanneer in het convenant der mensenrechten, opgesteld door de Commissie voor de mensenrechten uit de V.N. wordt opgenomen ,,Alle volkeren en naties hebben het recht van zelfbeschikking" - oorspronkelijk een Sovjet initiatief - wordt juist alleen gedacht aan de koloniale volkeren. Pogingen om hieraan een universele betekenis toe te kennen faalden, zodat aan volkeren in niet-koloniale gebieden het zelfbeschikkingsrecht als fundamenteel recht - wat het dan ook moge inhouden zou worden onthouden. Dat orators in de vergaderingen van de V.N. zich bedienen van een begrip, waarvan niemand precies weet, wat het eigenlijk inhoudt is niets bijzonders. Ook de begrippen volk en natie zijn ongedefiniëerd. Maar gevaarlijk wordt het wanneer geprobeerd wordt omschrijvingen van begrippen als zelfbeschikkingsrecht aanvaard te krijgen, die worden ingegeven door politieke opportuniteit. De definities van zelfbeschikkingsrecht, die in de vergaderingen der Verenigde Naties zijn naar voren gekomen, kunnen geen van alle worden gezien als ernstige pogingen tot een objectieve begripsbepaling. De gedelegeerde van Pakistan b.v. zocht het in het negatieve. Het zelfbeschikkingsrecht hield volgens hem een verbod in, nl. dat zwakke volkeren niet overheerst mogen worden door sterke volken. Joegoslavië meende de betekenis te moeten zoeken in bescherming tegen bedreiging van de onafhankelijkheid door andere staten. De Verenigde Staten wensten het beginsel toegepast te zien zowel op volkeren, die nog geen onafhankelijkheid hebben bereikt als op ,,political independent states which needed protection from external pressure, threats, the use of force and subversive activities". De afgevaardigde van Chili vond dat het zelfbeschikkingsrecht ,,alle staten, die in een of andere vorm van economische afhankelijkheid verkeerden, het recht moest geven de volle souvereiniteit te herwinnen, door het verwerven van volledige contrôle over zijn natuurlijke bronnen, zelfs indien dit de uitwijzing of nationalisatie van bepaalde ondernemingen zou betekenen". Volgens deze definitie houdt het recht dus een vrijbrief in tot confiscatie of onteigening tegen een eenzijdig te bepalen vergoeding van vreemde eigendommen.

Dat erkenning van een recht in die vorm alle bereidheid van buitenlandse investeerders en tot economische hulpverlening zou doden deert vele praters in de vergaderingen der Verenigde Naties niet.

Clyde EAgleton merkt naar aanleiding hiervan in een artikel „Excesses of selfdetermination” het volgende op: „With such aims self-determination loses all meaning, for it is extended to cover everything. Anything a "people" or a "nation" (provided it is a colony) whether already independent or not may desire it is entitled to have. It would include the right to the protection of collective security, and full protection for all nationalistic economic actions. No law would be allowed to stand in the way of what a group desired - or what an individual desired. The United Nations, which is asked to furnish these guarantees, would thus become the midwife of all groups desiring to be politically born. Its purpose would no longer be to uphold peace and 
justice but to assure to each "people" or "nation", anything it wanted, regardless of what other "peoples" having the same rights, might want".

Introductie van zulk een veelomstreden begrip in het statuut heeft dus zeker bezwaren, maar behoeft anderzijds toch geen onoverkomelijk struikelblok op te leveren voor de totstandkoming ervan, mits maar duidelijk wordt vastgelegd, wat partijen in de zin van het statuut onder zelfbeschikkingsrecht verstaan. Bij gebreke van een algemeen aanvaarde begripsbepaling ligt het voor de hand tot een ad hoc definitie te komen.

Waarschijnlijk hebben de Surinamers, toen ze vasthielden aan opname van het zelfbeschikkingsrecht in de preambule, zich de deterioratie van dit begrip in het internationaal gesprek niet gerealiseerd. Wat zij tot uitdrukking wilden brengen was, dat de verdere staatkundige evolutie van Suriname door het statuut niet moest worden afgesneden en dat de verhouding van Suriname tot de andere rijksdelen moet kunnen worden herzien indien de omstandigheden daartoe aanleiding zouden geven.

En nu was wel duidelijk, dat van die zijde onder het zelfbeschikkingsrecht ook een recht van secessie werd begrepen, niet omdat verwacht werd hiervan gebruik te maken, maar omdat zonder dat recht naar het gevoelen van de Surinamers niet alle mogelijkheden zouden zijn opengehouden.

Aangezien het hier een geschilpunt betrof, dat van een ander karakter werd geoordeeld dan de overige geschilpunten, achtte de Regering het wenselijk hiervoor een oplossing te zoeken vóór de hervatting van de conferentie. Een gelegenheid hiertoe bood het weder aan de orde komen van de kwestie van het beëindigen van de rapportage ex art. 73 e van het Handvest der Verenigde Naties over Suriname en de Nederlandse Antillen in de zevende algemene vergadering van de wereldorganisatie. Nederland had de indiening van rapporten gestaakt op grond van de overweging dat de beide rijksdelen op het terrein, waarop deze verslagen zich bewegen, volledig autonoom waren geworden en het daarvoor dus geen verantwoordelijkheid meer draagt. In 1952 hadden de algemeen vertegenwoordigers dezer rijksdelen het Nederlandse standpunt gesteund, uitgangspunten voor hun verdediging waren de zelfstandigheid hunner landen in interne zaken en het zelfbeschikkingsrecht dat Suriname en de Nederlandse Antillen bezitten.

De Nederlandse Regering deelde de Regeringen van de transatlantische rijksdelen October 1952 mede, dat haar vertegenwoordigers in de Nederlandse delegatie zo nodig konden verkla- 
ren, ,,dat zij het voortgaande overleg met Nederland ter R.T.C. verdedigen krachtens zelfbeschikkingsrecht" (Handelingen $2 e$ Kamer I953, 30e vergadering, blz. 504). Zij gaf dus hiermede te kennen geen bezwaar te hebben tegen het zelfbeschikkingsrecht als uitgangspunt der besprekingen.

Suriname vroeg toen om nadere precisering van de inhoud van dit begrip. Hieruit kwam een gedachtenwisseling voort, die eerder tot verwijdering dan tot toenadering der standpunten dreigde te leiden. Daarom werd besloten tot een bespreking te New York, waartoe Minister KERNKAMP zijn kennismakingsreis naar de transatlantische rijksdelen zou onderbreken.

Het resultaat van deze besprekingen werd vastgelegd in een memorandum van de volgende vijf punten:

„1. De grondslag van de voortzetting van het overleg voor de conferentie Nederland-Nederlandse Antillen-Suriname is dezelfde gebleven als die van de Conferentie van 1948, t.w. de gelijkwaardigheid en vrijwillige gebondenheid.

2. De grondwetswijziging van 1948 is het resultaat van de overeenstemming betreffende de vrijwillige verbondenheid, welke tijdens de Conferentie van 1948 is bereikt, welke Conferentie werd verdaagd en niet werd beëindigd ${ }^{1}$ ).

3. In aansluiting op het reeds gepleegd overleg heeft het statuut Hoofdstuk XIV van de grondwet in acht te nemen. Het moet dus uitgaan van de verbondenheid der drie rijksdelen. Daarmede is echter niet gezegd, dat dit statuut het eindpunt van de ontwikkeling der verhouding tussen de drie Rijksdelen behoeft te zijn. 4. Wanneer het statuut tot stand is gekomen is daarmede het bestaande Hoofdstuk XIV van de Grondwet uitgewerkt. Wijzigingen in de verhouding tussen de drie rijksdelen kunnen daarna worden aangebracht door herziening van het statuut, welke in onderling overleg op niet te moeilijke wijze zal moeten kunnen tot stand komen.

5. In de preambule van het statuut zal het zelfbeschikkingsrecht tot uitdrukking komen."

Dit memorandum en, meer nog, de daaraan tijdens 's Ministers bezoek aan Suriname gegeven interpretatie hebben aanleiding gegeven tot uitvoerige debatten in de Staten-Generaal.

In een desbetreffend memorandum van de Surinaamse Regering wordt o.m. gezegd: ,In de preambule komt echter tot uitdrukking dat de West-Indische Rijksdelen het zelfbeschikkings-

1) Dit is een ,,slip of the pen", ten rechte is de Conferentie bij K.B. van 26 Februari 1952 no 21 opgeheven. 
recht bezitten, zodat ze in de toekomst hiervan gebruik kunnen maken; een vrije keuze van Suriname en de Nederlandse Antillen t.o.v. hun status staat dus niets meer in de weg. Indien een der rijksdelen niet meer in het Koninkrijk wenst te blijven, moet dit verlangen door een wijziging van het statuut kunnen worden verwezenlijkt, zonder dat een der andere rijksdelen dit zal kunnen tegenhouden".

Uit het communiqué door de Minister afgegeven bij zijn terugkeer hier te landen citeren we de volgende passage: „De Surinaamse Regering is op basis van vrije keuze ten volle bereid, aan het tot stand komen van een statuut mede te werken en dat een absoluut faire kans te geven. $\mathrm{Zij}$ wil dit evenwel alleen, en dat is een tweede gewichtig punt, indien voor de toekomst op grond van het zelfbeschikkingsrecht alle mogelijkheden open gehouden worden. Die mogelijkheden omvatten uiteraard wijziging van het statuut en ook zelfs losmaking van de band met Nederland, als het Surinaamse landsbelang zulks onvermijdelijk mede zou brengen. Dit impliceert niet, dat Suriname op een gegeven ogenblik maar rauwelijks zou kunnen uittreden. Integendeel, men zal dan elkander raadplegen en altijd als eerste mogelijkheid handhaving van de koninkrijksband overwegen. Voorts zal men intern waarborgen scheppen om te voorkomen, dat de voorgenomen stap lichtvaardig zonder behoorlijke peiling van de gevoelens der bevolking genomen kan worden".

Uit de samenhang der mededelingen blijkt duidelijk dat de , ,ad hoc" interpretatie van het zelfbeschikkingsrecht, naar het gemeenschappelijk oordeel van Suriname en de Minister het recht van secessie inhoudt, maar een geclausuleerd recht van secessie. Er moet immers, ten genoege van de drie partners van het statuut, blijken dat de voorgenomen afscheiding inderdaad de wil der bevolking is, die op behoorlijke (democratische) wijze moet zijn gepeild. Voorts zal een en ander overeenkomstig punt 4 in onderling overleg tot stand moeten komen.

De meerderheid der Tweede Kamer zag in aanvaarding van deze interpretatie een gevaar, gesproken werd van een ,tijdbom onder het Koninkrijk".

Het wil voorkomen, dat de door de Minister gegeven ad hoc interpretatie, waarmede alle partijen accoord zouden moeten gaan en die dus de betekenis van het zelfbeschikkingsrecht in de zin van het statuut zou bepalen, minder gevaarlijk is dan het afhankelijk stellen van de inhoud van het zelfbeschikkingsrecht - in de zin van het statuut - van de ontwikkeling van het positieve 
internationale recht, waartoe de afgevaardigde Dr DE KoRT bereid was.

Het moge immers juist zijn dat het recht van secessie niet behoort tot het positieve recht, maar een ieder die het gebeuren in de Verenigde Naties volgt moet het wel duidelijk zijn, dat de ontwikkeling der opvattingen in die kring zich beweegt in de richting van erkenning voor de afhankelijke volkeren van een volledig recht van zelfbeschikking, met inbegrip van het recht van secessie, en dan waarschijnlijk een ongeclausuleerd secessierecht. Er zijn wat dit aangaat duidelijke tekenen aan de wand.

Dr DE KORT maakte een voorbehoud, n.l. dat het in het positieve internationale recht opgenomen recht van secessie in dermate zin redelijk zou zijn, dat het door Nederland zou worden erkend.

Uit zijn artikel ,,Zelfbeschikkingsrecht" van Maart 1953, blijkt, dat Dr DE KORT daarbij waarschijnlijk dacht aan internationaal rechtelijke waarborgen tegen misbruik, die het recht, ,in dermate zin redelijk" moeten maken, dat het voor Nederland - bedoeld zal zijn het driedelig Koninkrijk - aanvaardbaar is. In dit artikel noemt Dr DE KORT als normen waaraan nationaliteiten zouden moeten voldoen voor het verkrijgen van volledig zelfbeschikkingsrecht: een bepaalde omvang, uitgebalanceerde en ervaren politieke partijen, zekere economische kracht en zeker intellect, redelijke ervaring op het gebied van zelfbestuur en redelijke democratische rechten voor de burgers. Zonder nadere precisering zijn deze criteria echter zo vaag, dat een discussie hierover tot een babylonische spraakverwarring moet leiden.

Een poging tot het opstellen van meer bruikbare normen heeft alle kans in soortgelijke moeilijkheden te verzanden als de pogingen om factoren op te stellen voor de beoordeling of een gebied „,selfgoverning" is geworden. Hoe langer de Verenigde Naties hieraan dokteren, hoe onmogelijker deze opgave blijkt te zijn.

Zou een internationaal rechtelijke clausulering achterwege blijven - hetgeen waarschijnlijk is - of naar Nederlandse smaak onvoldoende zijn, dan zou de uitbreiding van het zelfbeschikkingsrecht in de gedachtengang van Dr DE KORT niet moeten worden erkend. Maar het Rijksdeel dat afscheiding beoogt zal zich hierdoor niet laten weerhouden om - gesteund door een goed deel der internationale publieke opinie - een beroep te doen op het dan tot het positief internationaal recht behorend recht van secessie. Neen, het lijkt zekerder in het zelfbeschikkingsrecht in de zin van het statuut het recht van secessie te begrijpen en liever dan zulks over te laten aan de onzekere inzichten van een internationaal gezelschap - dit in overleg met de statuut-partners zodanig te clausuleren, dat toch een zo groot mogelijke stabiliteit in de verhouding tot de transatlantische rijksdelen wordt bereikt. Deze waarborgen tegen misbruik zijn dan vrijwillig aanvaard en binden de deelgenoten over en weer. 
Voor de duurzaamheid der goede verstandhouding tussen de delen van het Koninkrijk zullen, naast de reële belangen, die door het samengaan worden gediend, mede bepalend zijn de redelijkheid en goede trouw waarmede getracht zal worden oplossingen te vinden voor de problemen, die uit het samengaan voortvloeien, ook indien zulk een probleem zou nopen tot een ingrijpende wijziging in de onderlinge staatkundige betrekkingen ${ }^{1}$ ),

Uit de debatten in de Tweede Kamer bleek duidelijk dat 's Ministers opvattingen inzake het zelfbeschikkingsrecht geen meerderheid konden vinden. Ook de Néderlandse Antillen keerden zich tegen een includering van het recht van secessie in het zelfbeschikkingsrecht. De Minister bleef van mening dat zijn oplossing de beste mogelijkheden inhield voor het overwinnen der impasse waarin de besprekingen waren verlopen, maar verklaarde zich in verband met nova, die zich hadden voorgedaan bereid te onderzoeken of een andere voor alle partijen aanvaardbare oplossing gevonden zou kunnen worden ${ }^{2}$ ).

Deze nova waren (1e) bereidheid van de zijde die zich daartegen vroeger het meest had verzet tot opname van het zelfbeschikkingsrecht in de preambule van het statuut en (2e) de hou-

1) Ook de bestrijders van 's Ministers interpretatie van het zelfbeschikkingsrecht menen overigens niet dat de mogelijkheid van secessie met statuutbepalingen en interpretaties daarvan uitgebannen kan worden. Integendeel. Dr DE KORT zei dienaangaande (Handelingen Tweede Kamer 1953 blz. 510 l.k.): ,,Het valt niet te ontkennen dat, indien te enigertijd de overgrote meerderheid der bevolking van een tot krachtige, voldoend omvangrijke nationaliteit volgroeid rijksdeel afscheiding zou willen, aan die afscheiding niet kan worden ontkomen." en Prof. GERRETson (Handelingen Eerste Kamer 1953 blz. 98 en 99): „,Men mene dan toch niet, dat Nederland het recht van secessie verwerpt, omdat wij de West met alle geweld in het Koninkrijk willen houden, en dat wij in de weigering van het $\mathrm{zg}$. recht van secessie willen doen uitkomen alsof men een Rijk met constitutionele bepalingen bij elkaar kan houden! Zo dwaas is Nederland niet. Wij willen de West niet in het Koninkrijk houden wanneer dit op den duur buiten het Koninkrijk zijn belangen beter kan behartigen. .... Wanneer het genoemde geval zich mocht voordoen, dan menen wij de redelijkheid van ons volk voldoende te kennen om zeker te zijn van een vriendschappelijke oplossing in onderling overleg. Artikel 4 [bedoeld is punt 4] van het Memorandum opent ook daartoe een constitutionele weg. En wanneer onze zonen wat minder redelijk zouden zijn: secessie is ook mogelijk zonder recht van secessie"'.

${ }^{2}$ ) Van sommige zijden is Minister Kernkamp verweten, dat hij door deze houding zichzelf verloochende. Ten onrechte. De Minister heeft nimmer verklaard, dat hij de zijns inziens beste oplossing ook de enig aanvaardbare achtte. 
ding van de Nederlandse Antillen t.o.v. 's Ministers interpretatie van het zelfbeschikkingsrecht. Aan het New Yorkse memorandum acht de Regering zich echter gebonden, dit zal de grondslag zijn van verdere besprekingen.

De Regering heeft toen een Commissie van drie (bestaande uit de Ministers Beel, Donker en Kernkamp) met deze taak belast. De drie ministers hebben een voorstel opgemaakt, naar aanleiding waarvan de Regering de volgende oplossing aan Suriname en de Nederlandse Antillen heeft voorgelegd:

In de preambule van het statuut wordt het zelfbeschikkingsrecht opgenomen, krachtens hetwelk de landen het statuut vrijwillig aanvaarden. De historische verbondenheid maakt plaats voor de vrijwillige verbondenheid. Het zelfbeschikkingsrecht in de zin van het statuut houdt niet in het recht der landen om de verhouding eenzijdig te beëindigen.

Aan de Surinaamse wensen om de mogelijkheden voor de toekomst open te houden wil men zoveel mogelijk tegemoet komen door wijziging van het statuut niet te moeilijk te maken. Normaal komt een voorstel tot wijziging bij gewone rijkswet tot stand, welke door de Koning niet wordt goedgekeurd alvorens het voorstel door Suriname en de Nederlandse Antillen bij landsverordening is aanvaard. Een en ander geschiedt bij gewone meerderheid van stemmen.

Houdt het wijzigingsvoorstel van het statuut een afwijking van de grondwet in, dan zal in Nederland de procedure voor grondwetswijziging moeten worden toegepast, echter met dien verstande, dat voor aanname in tweede lezing niet een meerderheid van 2/3 maar een gewone meerderheid wordt vereist.

Om nu de mogelijkheid van afwijking van de grondwet te beperken, is de Nederlandse Regering bereid zich te verbinden bij de eerstvolgende voorstellen tot wijziging van de grondwet na totstandkoming van het statuut, een voorstel op te nemen strekkende tot schrapping van het XIVe hoofdstuk betreffende de overgang naar de nieuwe rechtsorde en tot het doen vervallen voor zover betreft Suriname en de Nederlandse Antillen van de artikelen 62 tot 64 .

De in dit voorstel gegeven uitwerking aan punt 4 van het New Yorks memoranđum maakt dus alle gewenste wijzigingen in de staatkundige verhouding die binnen koninkrijksverband realiseerbaar zijn op niet te lastige wijze mogelijk.

Punt 3 van het memorandum zegt bovendien dat het statuut niet het eindpunt van de ontwikkeling der verhouding tussen 
de drie rijksdelen behoeft te zijn. Ook voor verdere ontwikkeling staat dus de weg van het overleg open. Mocht de ontwikkeling zo zijn, dat door wijziging van het statuut geen bevredigende aanpassing aan de nieuwe situatie mogelijk is, dan zal wel een andere oplossing moeten worden gevonden. Ondanks de uitsluiting van het recht van secessie behoeft te dien aanzien geen ongerustheid te bestaan. Indien de bevolking op democratische en weloverwogen wijze van zodanig verlangen zou doen blijken, is het in deze en de toekomstige wereld welhaast ondenkbaar, dat hieraan voorbij zou kunnen worden gegaan, gesteld dat men dat zou willen.

Een samengaan met Nederland heeft niet alleen zin als voortzetting van eeuwenoude relaties - welke politieke, culturele en economische banden overigens reëel genoeg zijn - maar dient de meest fundamentele belangen der rijksdelen overzee.

De verwevenheid der belangen is oorzaak, dat het buitenlands beleid een steeds groter rol gaat spelen in de nationale politiek. Het is politieke dagdromerij te menen, dat kleine gemeenschappen als de Nederlandse Antillen met een 160.000-tal en Suriname met een 200.000-tal inwoners in het internationaal overleg een zelfstandige rol zouden kunnen spelen. Het is evenzeer een illusie te veronderstellen, dat dergelijke kleine eenheden op zichzelf de kracht zullen kunnen opbrengen om weerstand te bieden aan de politieke, economische en culturele druk, waaraan zij ongetwijfeld zullen worden blootgesteld. Zulk een zwakke positie in een roerige wereld beinvloedt uiteraard de waardering van de waarborgen voor rechtszekerheid en deugdelijk bestuur, die de Overheid kan bieden. Dit kan de welvaart der beide gebieden en de toekomstverwachtingen van Suriname ernstig schaden, omdat hiermede de bedrijfszekerheid der oliebedrijven en der bauxietondernemingen, zomede de bereidheid om Suriname de steun te geven die zij behoeft voor de uitvoering van zijn ontwikkelingsplannen, in het hart worden geraakt.

Het zou van een fatale afwezigheid van politieke werkelijkheidszin getuigen, indien de realiteiten van het heden uit het oog zouden worden verloren ter wille van een naar ons gevoelen ongemotiveerde bezorgdheid voor wat zich mogelijk in de toekomst zal kunnen voordoen. 


\section{LITERATUUR}

BORDEWIJK, H. W. C.: Ontstaan en ontwikkeling van het staatsrecht van Curą̧ao. 's-Gravenhage, 1911.

Brandon, H. G.: Het Suriname vraagstuk. 's-Gravenhage, 1925.

Buiskool, J. A. E.: Surinaams staatsrecht. Amsterdam, 1937.

Eagleton, Clyde: Excesses of selfdetermination. Foreign Affairs July 1953.

Eberstein, Chion du Vervier: Remarques critiques sur le Tableau Historique. London, Amsterdam, 1779.

Edmundson, George: The Dutch in Western Guyana. The English Historical Review Iס, 1901.

Encyclopaedie van Nederlandsch West-Indië. 1914-1917.

GaAy Fortman, B. DE: Vijf en twintig jaren, 1898-1923. W.I.Gids jrg. 5, 1923.

GaAY Fortman, B. DE: Een aanvulling van Bordewijks Ontstaan en Ontwikkeling van het Staatsrecht van Curaçao. W.I. Gids jrg. 7. 1926.

GAay Fortman, B. DE: Schets van de politieke geschiedenis der Nederlandse Antillen in de 2oe eeuw. 's-Gravenhage, 1947.

Gedenkboek Nederland-Curaçao I634-I934, Amsterdam, 1934.

Gorsira, M. P. De staatkundige emancipatie van de Nederlandse Antillen. 's-Gravenhage, 1950.

Grol, G. J. van: De grondpolitiek in het West-Indische Domein der Generaliteit. 2 dln, 's-Gravenhage, 1934 en 1942.

Hamelberg, J. H. J.: De Nederlanders op de West-Indische Eilanden. 2 dln, Amsterdam, 1901 en 1903.

Hartsinck, J. J.: De beschrijving van Guiana. Amsterdam, 1770.

Helsdingen, W. H. van: De zelfstandigheid der eilandgebieden in de Nederlandse Antillen. W.I.Gids 32, 1951.

Hiss, PH. H.: Netherlands America. New-York, 1943.

Houven van Oordt, A. J. v. D.: Het Regeeringsreglement van Suriname.

KorT, W. L. P. M. DE: Zelfbeschikkingsrecht. Katholiek Staatkundig Maandschrift, Maart 1953.

LAET, JOANNES DE: Iaerlyck verhael van de verrichtinghen der Geoctroyeerde West Indische Compagnie, uitgegeven door S. P. L' HoNorÉ NABER. 's-Gravenhage, 1931.

Lier, R. A. J. vaN: Samenleving in een grensgebied. 's-Gravenhage, 1949.

Menkman, W. R.: De Nederlanders in het Caraïbische Zeegebied. Amsterdam, 1942.

Menkman, W. R.: De geschiedenis van de West-Indische Compagnie. Amsterdam, 1947.

Newton, A. P.: The European nations in the West Indies r493-r688. London, 1933

Oost en West 44, rfo I2, Suriname nummer, 24 December 1951.

Oost en West 45, no 5, Nederlandse Antillen nummer, 31 Mei 1952.

Palgrave, W. G.: Dutch Guiana. London, 1876.

Rapport van de Commissie tot onderzoek en bestudering van de in het staatsdeel Curaçao levende politieke opvattingen en wensen ter voorbereiding van de Rijksconferentie. 's-Gravenhage, 1946. 
Raynal, S. F.: Histoive philosophique et politique des établissements et du commerce des Européens dans les deux Indes. Amsterdam, 1773.

Rodway, J.: Guiana: British, Dutch and French London, 1912.

RoEтноF, H. J.: Het zelfbeschikkingsrecht der nationaliteiten. 's-Gravenhage, 1951.

Staal, G. J.: Vijf en twintig jaren, 1898-1923. W.I.Gids jrg. 5, 1923.

StaAl, G. J.: Nederlandsch Guyana. Amsterdam, (1928).

Teenstra, M. D.: De Nederlandsche West-Indische Eilanden. 2 dln, Amsterdam, 1836 en 1837.

Tuyl Schuitemaker-van Steenbergen, E.: Politieke ontwikkeling in Suriname na de inwerkingtreding der Interim-Regeling. W.I.Gids 32,1951

Verslag van de Commissie tot bestudering van staatkundige hervormingen in Suriname. Deel I, 's-Gravenhage, 1948. Deel II, Paramaribo, z.j.

Verslag van de Commissie van onderzoek naar de opvattingen in Nederland omtrent de plaats van de Overzeese Rijksdelen in het Koninkrijk. 's-Gravenhage, 1946.

Vollenhoven, C. van: Staatsrecht overzee. Leiden, 1934.

West-Indische Gids, De, diverse jaargangen.

Wolbers, J.: De Geschiedenis van Suriname. Amsterdam, 1861.

Wijnmalen, TH. C. L.: Les possessions néerlandaises dans les Antilles. Revue Coloniale 2, 1887.

\section{S U M M A R Y}

\section{MAIN FEATURES OF THE DEVELOPMENT OF SURINAM AND THE NETHERLANDS ANTILLES}

The trade of the English, the French and the Dutch to the Caribbean area in the wake of the Spanish, had originally a commercial, but later on also a strategic purpose, namely the interception of the treasures with which Spain financed her wars against rising new nations.

The Netherlanders found a harbour in Curaçoa which offered an excellent refuge and which gave the island ideal opportunities for establishing an emporium for the traffic in slaves and goods. St. Eustatius also was favourably situated for this purpose. Salt and dyewood of the islands of the Leeward Group, off the Venezuelan coast, were products in great demand

British, French and Netherlands colonists settled in the Guianas, situated on the demarcationline by which in 1494 the POPE had divided the world in two spheres of influence, namely one assigned to Spain and the other to Portugal.

The struggle for hegemony in the Guianas between the British and the "Zeeuwen" (Sealanders) ended to the advantage of the latter. The „Zeeuwen" transferred their rights in Surinam to the West-Indian Company which conveyed a one-third share to Amsterdam and another one-third share to the Hon. van Aerssen van Sommelsdijck. Together they founded the "Geoctroyeerde Societeit van Suriname" (Chartered Society of Surinam).

For those times the Charter of 1683 by which this Colony was ruled 
until the dissolution of the West-Indian Company (actually till 1816), breathed a liberal spirit.

Surinam became a thriving plantation-colony, its prosperity being founded on slave labour. The article recounts the principal circumstances of the American possessions, the constitutional relations and the economical rise and decline during this period.

From the end of the Napoleonic period until the introduction of the Government-regulations of 1869 repeatedly constitutional modifications were made, among others those required first for the union of Surinam and the Antilles, and then the division in 1845 .

The Government-regulations of 1869 meant a modernisation of the public institutions. Surinam was granted a people's representation, the "Koloniale Staten", partly elected by a limited number of electors. Curaçoa and Dependencies had to be content with a nominated "Koloniale Raad" (Colonial Council). The Government-regulations were revised several times, the most important revision being the one in 1936 by which the influence of the population on the government proceedings was enhanced.

Since 1869 the colonies had had the right of budget which was subject to certain restrictions however. The most important of these restrictions was that the approval of the budget should take place in the Netherlands if it showed a deficit. As the economic situation had deteriorated and both territories had become financially dependent (Curaçoa till 1929. Surinam till 1940) this right of budget was not of much importance. There was hardly any affair in which the Crown or the Parliament could not have the last word.

After the world-war the difficulties in Indonesia accounted for the fact that the introduction of the new jurisdictional order envisaged in the speech of H. M. THE QUEEN of the 7th of December 1942 had to be postponed.

In 1948 several important modifications were introduced into the Government-regulations. A semi-parliamentary responsibility of the people's representation ("Staten") to be elected by general suffrage was created. In the same year a revision of the Constitution of the Netherlands was effected which took away constitutional objections against further reforms.

A round-table conference was held in 1948. Complete autonomy in internal affairs and a provisional arrangement as regards the participation in the care of joint interests was enforced by law for Surinam in 1950 and for the Netherlands Antilles in 1951.

For the Netherlands Antilles, Islands-regulations were introduced in 1951, granting a territorial autonomy to the islands.

The completion of the reforms: the realisation of a Statute to be accepted voluntarily by the different parts of the Realm and by which the new jurisdictional order is being established, has yet to follow. A conference held to this end in 1952 had to be adjourned because of some differences of opinion for which at that time a solution could not be found.

An exposition of the nature of the principal differences and the direction in which solutions are being looked for concludes the article. 